\title{
Análise geológico-geomorfológica da região noroeste da llha de São Sebastião, São Paulo: diques mesozoicos básicos e intermediários como condicionantes do relevo
}

\author{
Geological-geomorphological analysis of the northwest region of São Sebastião Island, \\ São Paulo, Brazil: basic and intermediate Mesozoic dikes as morphogenetic determinants
}

\author{
Flávio Henrique Rodrigues ${ }^{1} \oplus$, Victor Arroyo da Silva do Valle ${ }^{2}$, José Eduardo Zaine ${ }^{1} \oplus^{\circledR}$, \\ Rodrigo Irineu Cerri ${ }^{3}$ (i), André de Andrade Kolya ${ }^{3}$, George Luiz Luvizotto 4 (D) \\ "Universidade Estadual Paulista "Júlio de Mesquita Filho" - UNESP, Instituto de Geociências e Ciências Exatas, \\ Departamento de Geologia Aplicada - IGCE/DGA, Avenida 24 A, 1515, CEP 13506-900, Rio Claro, SP, BR \\ (rodrigues.ambiental@gmail.com; jezaine@rc.unesp.br) \\ ${ }^{2}$ Prefeitura de Santos, Departamento de Proteção e Defesa Civil, Coordenadoria de Risco \\ Tecnológico e Natural, Santos, SP, BR (victorarroyo@santos.sp.gov.br) \\ 3UNESP, IGCE, Programa de Pós-graduação em Geociências e Meio Ambiente, \\ Rio Claro, SP, BR (roocerri@gmail.com; andrek42@gmail.com) \\ ${ }^{4}$ UNESP, IGCE, Departamento de Petrologia e Metalogenia, Rio Claro, SP, BR (georgell@rc.unesp.br)
}

Recebido em 18 de maio de 2018; aceito em 26 de julho de 2019

\begin{abstract}
Resumo
$\mathrm{Na}$ Ilha de São Sebastião (SP), a diversidade geomorfológica está diretamente associada às distintas unidades geológicas, como embasamento pré-cambriano granito-gnáissico e intrusões mesozoicas representadas por dois principais conjuntos: rochas toleíticas vinculadas ao rifteamento do Atlântico Sul (Eocretáceo — aprox. 130 Ma) e magmatismo alcalino (Neocretáceo - aprox. $70 \mathrm{Ma}$ ) da plataforma meridional brasileira. O objetivo deste trabalho foi analisar as características e propriedades litoestruturais dos diques básicos e intermediários intrudidos nos granitoides da porção noroeste da referida ilha, correlacionando-os aos distintos padrões de relevo, ou seja, feições positivas, como as cristas alongadas mais resistentes ao intemperismo e erosão, e feições negativas menos resistentes, como os vales encaixados. Por meio de medições de campo, análise petrográfica e geoprocessamento, constatou-se que a composição mineralógica e o padrão de fraturamento do embasamento e dos diques, bem como a espessura destes, são os principais fatores responsáveis pelas diferentes respostas aos processos superficiais. Os diques que condicionam as drenagens são representados por diabásios de textura variada, apresentando minerais máficos (clinopiroxênio e olivina) e plagioclásio cálcico (labradorita). Essa mineralogia se mostra mais susceptível quando comparada àquela presente nos diques associados às cristas alongadas, representados por andesitos porfiríticos, com menor proporção de minerais máficos, além de o plagioclásio presente ser predominantemente de composição sódica (oligoclásio). Verificou-se ainda que os diques de diabásio são menos espessos e têm maior densidade de fraturamento. As unidades geológicas presentes na área de estudo foram classificadas da mais suscetível a mais resistente aos processos exógenos, da seguinte maneira: diques de diabásio, embasamento granito-gnáissico e diques andesíticos.
\end{abstract}

Palavras-chave: Condicionantes litoestruturais do relevo; Diques mesozoicos básicos e intermediários; Erosão diferencial; Susceptibilidade ao intemperismo.

\footnotetext{
Abstract

In São Sebastião Island (SP), geomorphological diversity is directly associated with distinct geological units, such as granite-gneiss precambrian basement and Mesozoic intrusions represented by two main sets: tholeiitic rocks connected to the South Atlantic rift (Eocretaceous - approx. $130 \mathrm{Ma}$ ) and alkaline magmatism (Neocretaceous - approx.. $70 \mathrm{Ma}$ ) from the Brazilian southern shelf. The aim of this work is to analyze the lithostructural characteristics and properties of the basic and intermediate dykes intruded in the granitoids of the northwestern part of the island, correlating them to the different geomorphological patterns, that is, positive features such as the elongated crests
} 
more resistant to weathering and erosion, and less resilient negative features such as the embedded valleys. It was observed, through field measurements, petrographic analysis and geoprocessing, that the mineralogical composition and fracture pattern of the basement and dikes, as well as their thickness, are the main factors responsible for the different responses to the superficial processes. The dykes associated to drainage are represented by diabase of varied texture, presenting mafic minerals (clinopyroxene and olivine) and calcium plagioclase (labradorite). Such mineralogy is more susceptible when compared to that present in the dykes in the elongated ridges, represented by porphyritic andesites with lower proportion of mafic minerals, in addition to the plagioclase being predominantly of sodium (oligoclase) composition. Diabase dikes are less thick and have higher fracture density. The geological units that occur in the study area are classified according to their susceptibility to exogenous processes, from the most susceptible to the most resistant one, as follows: diabase dikes, granite-gneiss basement, and andesitic dikes.

Keywords: Litho-structural factors of relief; Mesozoic basic and intermediaries dykes; Differential erosion; Susceptibility to weathering.

\section{INTRODUÇÃO}

Pesquisas e trabalhos sobre evolução do relevo objetivam tanto o desenvolvimento da ciência, buscando melhor entendimento sobre essa dinâmica de paisagem, como também suas aplicações no cotidiano, visando à melhor gestão do ambiente no qual vivemos e extraímos recursos essenciais à vida moderna. Desse modo, ao entender como se dá a dinâmica que molda a superfície terrestre (processos, produtos e taxas), é possível aprimorar as medidas de prevenção e solução de problemas ligados à ocupação do meio físico pelo ser humano (Anjos e Veneziani, 1993).

As formas individualizadas do relevo são o resultado da dissecação diferenciada de litotipos, ou seja, são registros da interação entre o ciclo das rochas e as condições ambientais ao longo do tempo (Griffiths et al., 2012). O antagonismo dessas forças, endógenas e exógenas, é a chave para compreensão dos processos geradores das formas de relevo, pretéritos e atuais, os quais são condicionados pelo clima, pelas características e propriedades das rochas e pelo tempo de exposição aos agentes intempéricos físicos, químicos e biológicos (Penck, 1953; Ross, 1992).

Os principais fatores inerentes à rocha que controlam a intensidade do intemperismo consistem na mineralogia, textura e estrutura, e são determinantes na diversidade das formas de relevo, tendo em vista que diferentes tipos litológicos respondem de formas distintas a processos semelhantes (Santos, 1994). A textura e a estrutura da rocha influenciam a infiltração de água. Feições como foliações, fraturas, acamamentos, estratificações etc., são descontinuidades no maciço rochoso que facilitam a percolação de água, aumentando a porosidade e tornando-o mais suscetível ao intemperismo (Magalhães e Cella, 1998). A influência da mineralogia reside no fato de que os minerais são formados sob condições extremas quando comparadas com a superfície terrestre, na qual são remobilizados até atingir uma forma mais estável.

Um exemplo da interação desses atributos litoestruturais é encontrado na Ilha de São Sebastião, no litoral paulista, caracterizada por relevos acidentados com elevações que atingem mais de $1.000 \mathrm{~m}$ de altitude, sustentados por rochas de variadas composições e estruturações. Entre as litologias presentes, destacam-se o embasamento cristalino granito-gnáissico, diques de rochas básicas e intermediárias, e stocks e diques de composições alcalina e ultrabásica.

A diversidade de elementos geomorfológicos está associada principalmente às propriedades químicas e estruturais intrínsecas a cada litotipo, uma vez que estão sujeitos às mesmas condições climáticas. Entre as formas resultantes do processo de denudação diferencial, os diques básicos e intermediários mostram interessante resposta do relevo. Por vezes, são associados a grandes cristas alongadas, ou seja, feições positivas mais resistentes ao intemperismo e erosão, as quais, inclusive, influenciam a morfologia da costa. Em outros casos, definem o entalhe da drenagem, representando feições negativas menos resistentes aos processos superficiais.

Nesse contexto, o objetivo do trabalho foi identificar e analisar as propriedades litoestruturais dos diques mesozoicos básicos e intermediários, intrudidos no embasamento pré-cambriano, determinantes na sua resistência aos processos geológicos superficiais e, portanto, responsáveis pelas diferentes formas de relevo associadas.

\section{CARACTERIZAÇÃO DA ÁREA DE ESTUDO}

A área de estudo é a região noroeste da Ilha de São Sebastião, a maior do município de Ilhabela, localizado no litoral norte do Estado de São Paulo (Figura 1). O território do município é formado pelo arquipélago homônimo, com aproximadamente $346 \mathrm{~km}^{2}$ e população estimada de 33 mil habitantes (IBGE, 2010).

O município caracteriza-se pelo alto índice de preservação da Mata Atlântica, com $78 \%$ do território protegidos pelo Parque Estadual de Ilhabela (PEIb), uma unidade de conservação de proteção integral. O clima 


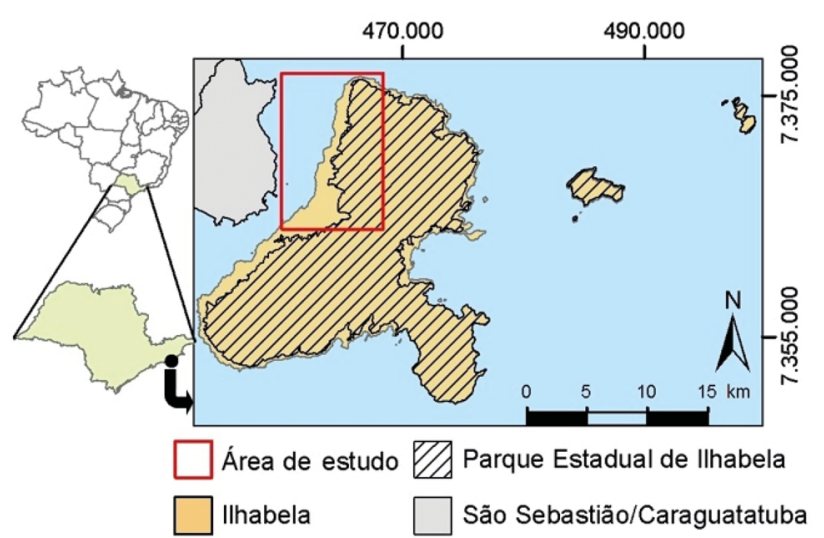

Figura 1. Localização da área de estudo.

da ilha é do tipo tropical chuvoso, com inverno seco (Köppen - Am) e temperaturas médias relativamente altas (FFSP, 2015).

\section{Geologia e geomorfologia}

A Ilha de São Sebastião tem sua gênese marcada por sucessivos eventos magmáticos associados à abertura do oceano Atlântico Sul durante a Era Mesozoica, que atingiram toda a porção meridional do território brasileiro. Porém, o embasamento granito-gnáissico mostra evolução geológica consideravelmente mais antiga, datando do pré-cambriano. $\mathrm{O}$ território da ilha se encontra inserido na Província Mantiqueira, um sistema orogênico Neoproterozoico que resultou na amalgamação do paleocontinente Gondwana Ocidental, durante o Ciclo Brasiliano - Pan-africano, precisamente no cinturão orogênico Ribeira (Schobbenhaus e Brito Neves, 2003; Hasui, 2012).

A Ilha de São Sebastião é composta por rochas metamórficas e ígneas pré-cambrianas, rochas ígneas mesozoicas e depósitos sedimentares recentes (Figura 2). As rochas pré-cambrianas são constituídas principalmente de gnaisses, migmatitos, metagranitoides diversos e possíveis charnockitos. Suas idades ainda são discutidas, sendo consideradas arqueanas (Almeida et al., 1981), pré-cambrianas médias a superiores (Silva et al., 1977) e pré-cambrianas indiferenciadas (Hasui et al., 1984).

Os gnaisses se apresentam como:

- granítico subequigranular e félsico-máfico bandado, ambos associados a veios ptigmáticos, transições para migmatitos e lentes de anfibolito e hornblenda gnaisse concordantes com a foliação;

- granítico oftálmico, este mais abundante.

O metagranitoide, por sua vez, ocorre como corpos que atingem dimensões quilométricas, apresentando fenocristais centimétricos de feldspato alcalino orientados segundo a foliação regional. São descritos ainda intrusões menores de leucogranito sub a equigranular médio a grosso, bem como diques de granodiorito equigranular fino a médio, metamórfizados e deformados segundo a foliação regional (Freitas, 1947; Barreto, 2016).

Seguindo a estruturação regional do Complexo Costeiro, os litotipos descritos acima apresentam foliação de direção NE-SW. No caso da Ilha de São Sebastião, a foliação principal apresenta alto ângulo, mergulhando principalmente para noroeste, bem como veios de quartzo deformados e zonas de cisalhamento (Riccomini et al., 2005).

As intrusões ígneas mesozoicas envolvem diferentes litotipos, desde rochas ultramáficas até hololeucocráticas, de composição ultrabásica, básica, intermediária e alcalina, que ocorrem na forma de diques e stocks, associados a três estágios magmáticos principais (Tabela 1).

O magmatismo vulcânico inicial (Cretáceo Inferior) envolve a maioria dos diques intrudidos no complexo pré-cambriano. Estes são representados principalmente por diabásio e andesito, e apresentam orientação subparalela à foliação do embasamento.

O plutonismo principal (Cretáceo Superior) é representado pelos três maiores stocks alcalinos, denominados São Sebastião, Serraria e Mirante. As principais rochas presentes são sienito com feldspatoides (pulaskito), saturados, e com quartzo (nordmarkito); nefelina sienito (tinguaito) e álcali-feldspato sienito. São rochas leucocráticas a hololeucocráticas, de granulação grossa, coloração cinza-clara a branca e estrutura que varia de maciça a acamadada. Ocorrem também na ilha gabro, diorito, piroxenito

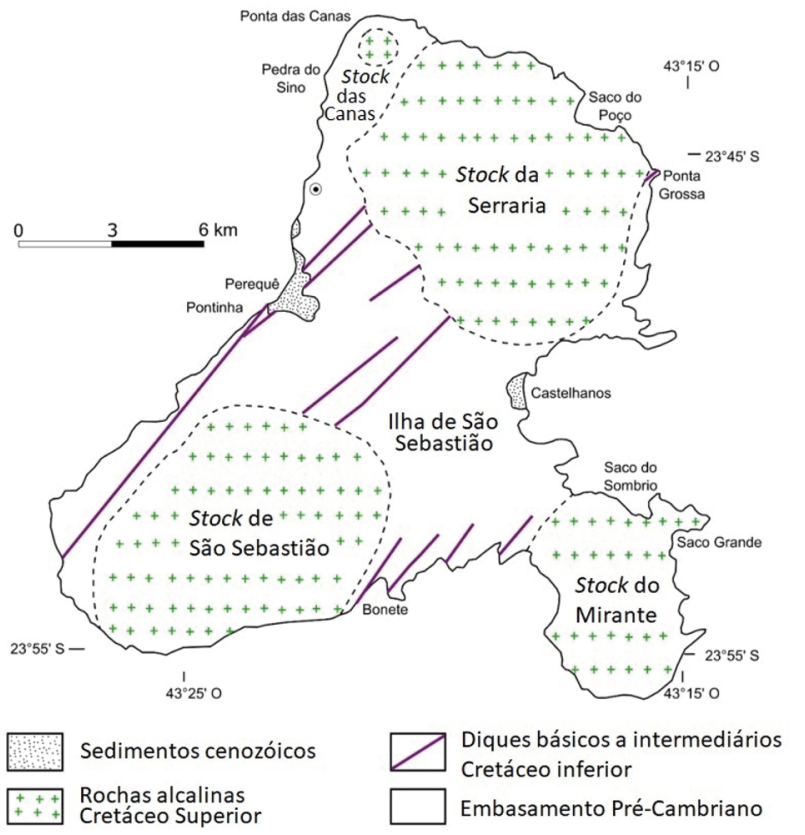

Fonte: Hennies e Hasui (1977).

Figura 2. Mapa geológico da llha de São Sebastião 
Tabela 1. Cronoestratigrafia do Mesozoico para as rochas da llha de São Sebastião.

\begin{tabular}{|c|c|c|c|c|c|c|c|c|c|}
\hline \multirow{3}{*}{\multicolumn{2}{|c|}{ 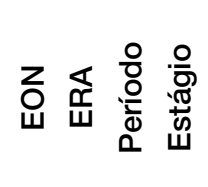 }} & \multirow{3}{*}{$\begin{array}{l}\sum_{0}^{\pi} \\
0 \\
0 \\
\frac{0}{0} \\
\underline{0}\end{array}$} & \multicolumn{7}{|c|}{ Rochas datadas pelo método $\mathrm{K}-\mathrm{Ar}$} \\
\hline & & & \multicolumn{2}{|c|}{$3^{\text {a }}$ fase } & \multicolumn{4}{|c|}{$2^{\mathrm{a}}$ fase } & $1^{a}$ fase \\
\hline & & & Traquito & Fonolito & Sienito & $\begin{array}{c}\mathrm{Na} \\
\text { Sienito }\end{array}$ & $\begin{array}{l}\text { Monzogabro/ } \\
\text { Monzosienito }\end{array}$ & Gabro & $\begin{array}{l}\text { Basalto de composição } \\
\text { básica a intermediária }\end{array}$ \\
\hline \multirow{11}{*}{ 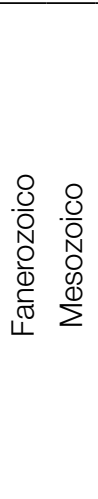 } & \multirow{11}{*}{ 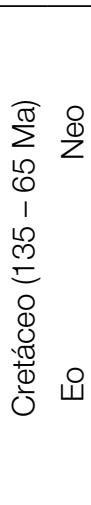 } & 65 & & & & & & & \\
\hline & & 72 & 70,03 & & & & & & \\
\hline & & 83 & 83,17 & 87,23 & 77,42 & & & 735 & \\
\hline & & 87 & & & 89,00 & 79,32 & 83,31 & 13,5 & \\
\hline & & 88 & & & & 91,88 & & & \\
\hline & & 92 & & & & & & & \\
\hline & & 96 & & & & & 100,93 & 102,5 & \\
\hline & & 108 & & & & & & & \\
\hline & & 113 & & & & & & & \\
\hline & & 117 & & & & & & & \\
\hline & & $\begin{array}{l}123 \\
131\end{array}$ & \multicolumn{6}{|c|}{ Magmatismo da Serra Geral 137 - 127 Ma } & $\begin{array}{c}\text { Intrusões de afinidade básica a } \\
\text { intermediária }\end{array}$ \\
\hline
\end{tabular}

Fonte: Sato (2006).

e equivalentes alcalinos. Exemplos dessas ocorrências são descritos na Ponta do Pacuíba, na Pedra do Sino e na Praia do Jabaquara, em que ocorrem essexito, ijolito e gabro nefelinítico (Hennies e Hasui, 1968; Montes-Lauar, 1993; Timich et al., 2016).

O magmatismo hipoabissal a subvulcânico final (Cretáceo Superior) é representado por diques, veios e intrusões menores que cortam os stocks do magmatismo principal. São predominantemente de composição alcalina e variam de rochas hololeucocráticas a ultramáficas. Suas texturas também são variáveis: ocorrem como rochas afaníticas, faneríticas finas a médias e grossas pegmatoides. Os principais litotipos descritos são piroxenito, teschenito, microgabro, microssienitos diversos, fonolito, diabásio e traquito (Lima, 2001). Dada a tamanha variação em diversos aspectos relacionados a esse grupo de rochas, é estimado que vários eventos magmáticos, não necessariamente relacionados geneticamente entre si, foram responsáveis pela sua geração (Garda, 1995; Timich et al., 2016; Pabst, 2014).

Os depósitos neógenos são representados por terraços marinhos, alçados a mais de $20 \mathrm{~m}$, localizados principalmente junto às planícies do Perequê, Castelhanos e Bonete (Freitas, 1944; França, 1954). Os sedimentos quaternários correspondem aos depósitos de encostas e fundo de vales de composição e granulometria variadas, tais como colúvio, tálus e sedimentos flúvio-marinhos (Rodrigues e Zaine, 2013; Diniz et al., 2016).

Quanto à geomorfologia, a Ilha de São Sebastião caracteriza-se pelo relevo novo, com amplitudes topográficas que ultrapassam $1.000 \mathrm{~m}$ e alto índice de dissecação vertical (Rossi et al., 2005; Rodrigues, 2018). Ramalho (1982) identificou vestígios de superfícies de aplainamentos, deformadas tectonicamente por intrusões de rochas alcalinas, dissecadas em morros nos stocks de São Sebastião e Serraria. Tais formas de relevo foram correlacionadas às superfícies dissecadas do Planalto Atlântico. Freitas (1944) destacou que as características mais marcantes são a presença de relevos senis, alçados a níveis topográficos distintos, ao lado de topografias jovens, fortemente dissecadas decorrentes de eventos epirogenéticos. O modelado costeiro encontra-se sob intensa abrasão marinha resultante de ciclos erosivos pós-Cretáceo, incidentes sobre as rochas e estruturas pré-cambrianas e, localmente, intrusões alcalinas, resultando no predomínio de praias embutidas entre esporões (Ramalho, 1982; Freitas, 1947).

\section{METODOLOGIA}

\section{Levantamento bibliográfico e organização da base cartográfica}

Foram consultados trabalhos técnicos e científicos referentes à geologia regional e local da Ilha de São Sebastião e à fundamentação teórico-metodológica, com destaque para análise fotogeológica, petrologia ígnea, intemperismo e os fatores que controlam sua intensidade. Para a criação da base de dados georreferenciados, foi definido o sistema de coordenadas UTM e datum SIRGAS 2000, Zone 23S. Utilizando o software o ArcGis 10.3, foram vetorizadas as cartas topográficas da área de estudo, elaboradas pelo Instituto Geográfico e Cartográfico do Estado de São Paulo (IGC, 1978), escala de 1:10.000, com equidistância das 
curvas de nível de $5 \mathrm{~m}$. Utilizaram-se também fotografias aéreas da Empresa Paulista de Planejamento Metropolitano S.A. (EMPLASA, 2011), com resolução espacial de $0,45 \mathrm{~m}$. Foi gerada apenas uma carta hipsométrica e de declividade, bem como sua combinação, segundo as recomendações de Tinós et al. (2014). As cartas de relevo sombreado permitiram a análise complementar de grandes alinhamentos de relevo, os quais não foram observados na etapa de fotointerpretação.

\section{Fotogeologia e caracterização geológico-geomorfológica}

Baseado no método lógico-sistemático proposto por Soares e Fiori (1976) e revisado por Zaine (2011), procedeu-se à etapa de fotointerpretação. Inicialmente, foram reconhecidos os padrões fisiográficos, por meio da análise e classificação do traçado da rede de drenagem, perfis de encosta, formas dos topos e vales e alinhamentos. Tais atributos foram interpretados, a fim de caracterizar as formas de relevo associadas aos diques quanto às propriedades e às características litoestruturais (petrografia, atitude das camadas, fraturas, falhas e tropia) bem como aos níveis de alteração do relevo (resistência à erosão).

A coleta de dados in situ se deu por meio da análise de afloramentos rochosos, com foco na descrição dos litotipos presentes e na caracterização geomorfológica (Figura 3). Foi realizada análise detalhada de 8 diques de diabásio e de 10 diques de andesito, referentes a espessura, comprimento, continuidade, orientação, padrão de fraturamento, composição mineralógica, textura e estrutura. Foram coletadas amostras para descrições petrográficas em escalas macro e microscópica.

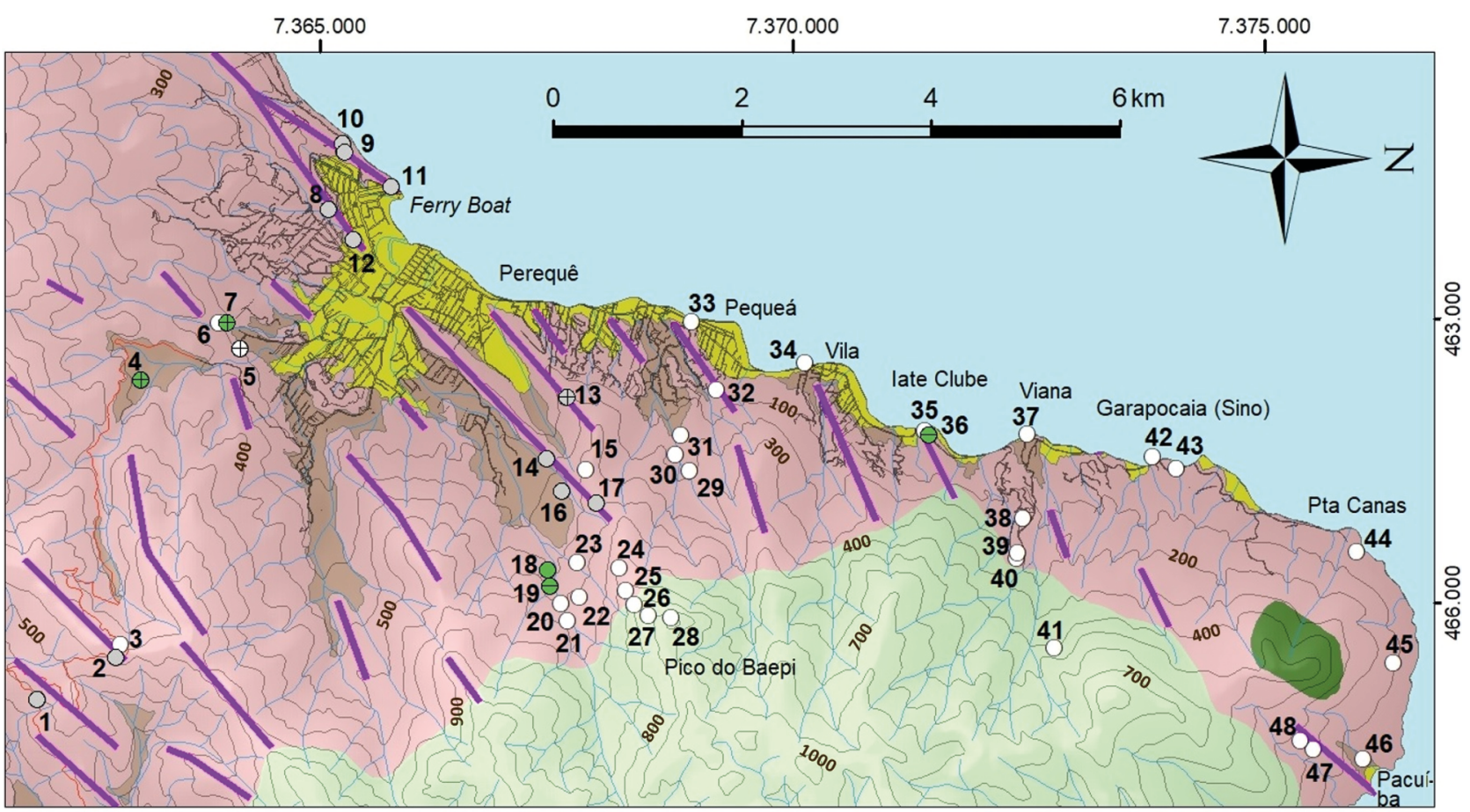

Pontos de Campo

Unidades Geológicas

Andesito

Diabásio

Ponto visitado

Amostra coletada

Lâmina

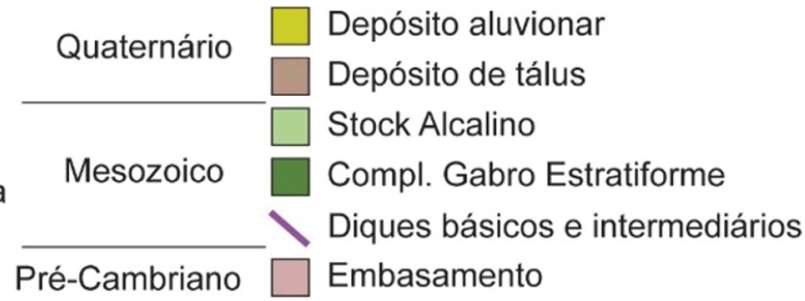

Depósito de tálus

Stock Alcalino

Embasamento
Convenções Cartográficas

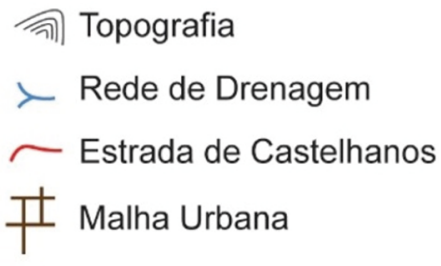

$\succ$ Rede de Drenagem

— Estrada de Castelhanos

† Malha Urbana

Figura 3. Mapa geológico simplificado com indicação dos pontos descritos em campo. 


\section{Análise dos dados e integração dos resultados}

As unidades geológicas identificadas em campo foram caracterizadas visando avaliar os fatores relacionados à suscetibilidade litológica ao intemperismo. Três fatores foram analisados: composição mineralógica, padrão de fraturamento e relevo associado. A composição mineralógica das rochas foi descrita por meio de microscopia ótica, utilizando-se quatro amostras representativas dos principais litotipos que ocorrem na área de estudos: uma do embasamento (gnaisse granítico oftálmico; ponto $5 \mathrm{da}$ Figura 3), uma de diques associados às feições positivas de relevo (andesito porfirítico; ponto 13) e duas de diques associados às feições negativas de relevo (diabásio intergranular e porfirítico; pontos 4 e 7). A análise do padrão de faturamento centrou-se principalmente na orientação e espaçamento de cada família de fratura. As formas de relevo, uma vez caracterizadas, foram associadas às rochas nesses locais, com o intuito de avaliar como diferentes propriedades litoestruturais influenciariam nas feições positivas e negativas do relevo.

\section{RESULTADOS}

\section{Análise geomorfológica}

O relevo da Ilha de São Sebastião reflete os eventos tectônicos e ciclos erosivos posteriores ao magmatismo neocretáceo do litoral sudeste brasileiro, que resultaram na grande variedade de litotipos ígneos e metamórficos encontrados em condições geomorfológicas diversas. $\mathrm{O}$ alinhamento das cristas, o escalonamento da linha de costa e a instalação de vales profundos e encaixados têm linearidade regular fortemente influenciada pelas estruturas pré-cambrianas, com direção NE e mergulho NW. As cristas associadas aos diques retilíneos se destacam na topografia, principalmente nos terrenos mais dissecados, junto à linha de costa e caracterizam-se pela assimetria de suas encostas, com o lado mais íngreme voltado para SW. Os vales seguem o mesmo padrão estrutural, apresentando-se assimétricos e encaixados em fraturas e falhas, nas quais é comum a presença de diques no leito dos cursos d'água (Figura 4). A morfologia da linha de costa também tem influências adicionais, associadas diretamente às intrusões alcalinas, as quais também se destacam como alinhamentos circulares de relevo na forma de superfícies estruturais truncadas por sistemas de fraturas e grandes falhamentos (fotointerpretados) com direção preferencial NE. Essas feições não se limitam aos terrenos alcalinos, ocorrendo em domínio gnáissico em que a morfologia circular define o alinhamento circular de cristas e a inflexão da linha de costa no extremo norte da área.

\section{Análise geológica}

\section{Embasamento granito-gnáissico}

Associa-se a tais litotipos um relevo de morros com encostas convexas e topos arredondados, presente em um nível menos elevado que as cristas retilíneas e os picos montanhosos representados, respectivamente, pelos diques e stocks alcalinos. Os litotipos representativos do embasamento granito-gnáissico na área de estudo são: gnaisse granítico oftálmico e gnaisse granítico subequigranular. Os diques que são objetos de estudo do presente trabalho se encontram intrudidos nessa unidade, exibindo orientação subparalela à foliação descrita nas rochas.

\section{Caracterização petrográfica}

As rochas apresentam composição granítica, sendo compostas de plagioclásio, quartzo, feldspato potássico e biotita e/ou muscovita.

O gnaisse granítico oftálmico (Figura 5) é cinza-claro quando fresco e varia de cinza-esbranquiçado a laranja-esbranquiçado quando alterado. É composto de plagioclásio (oligoclásio), quartzo, feldspato potássico (microclínio), biotita e hornblenda. A rocha exibe textura porfiroblástica, com cristais grossos $(1-4 \mathrm{~cm})$ de feldspato potássico em matriz média $(1-5 \mathrm{~mm})$ subequigranular composta de plagioclásio, quartzo, feldspato potássico, biotita e hornblenda. A estrutura é gnáissica, com foliação definida por orientação preferencial de cristais de biotita e fenocristais de feldspato potássico.

O gnaisse granítico oftálmico é o principal representante do embasamento granito-gnáissico, aflorando praticamente em toda a extensão da ilha. No ponto 18 (Figura 3), foi descrita uma variação de tal litotipo (Figura 6), com bandamento composicional pronunciado formado por bandas com predominância de minerais félsicos (plagioclásio, quartzo e feldspato potássico) intercaladas a bandas em que minerais máficos predominam (biotita e hornblenda).

O gnaisse granítico subequigranular foi observado somente em um local (ponto 36). É uma rocha clara, de cor branco-rosada quando fresca e cor esbranquiçada quando alterada, sendo composta por feldspato potássico, quartzo, plagioclásio, muscovita e biotita (Figura 7). Apresenta estrutura gnáissica, com foliação definida pela orientação dos cristais constituintes. A foliação tem direção nordeste com mergulhos de alto ângulo predominantemente para sudeste.

\section{Aspectos estruturais}

As principais estruturas presentes nas rochas do embasamento incluem a foliação principal e três famílias de fraturas. 


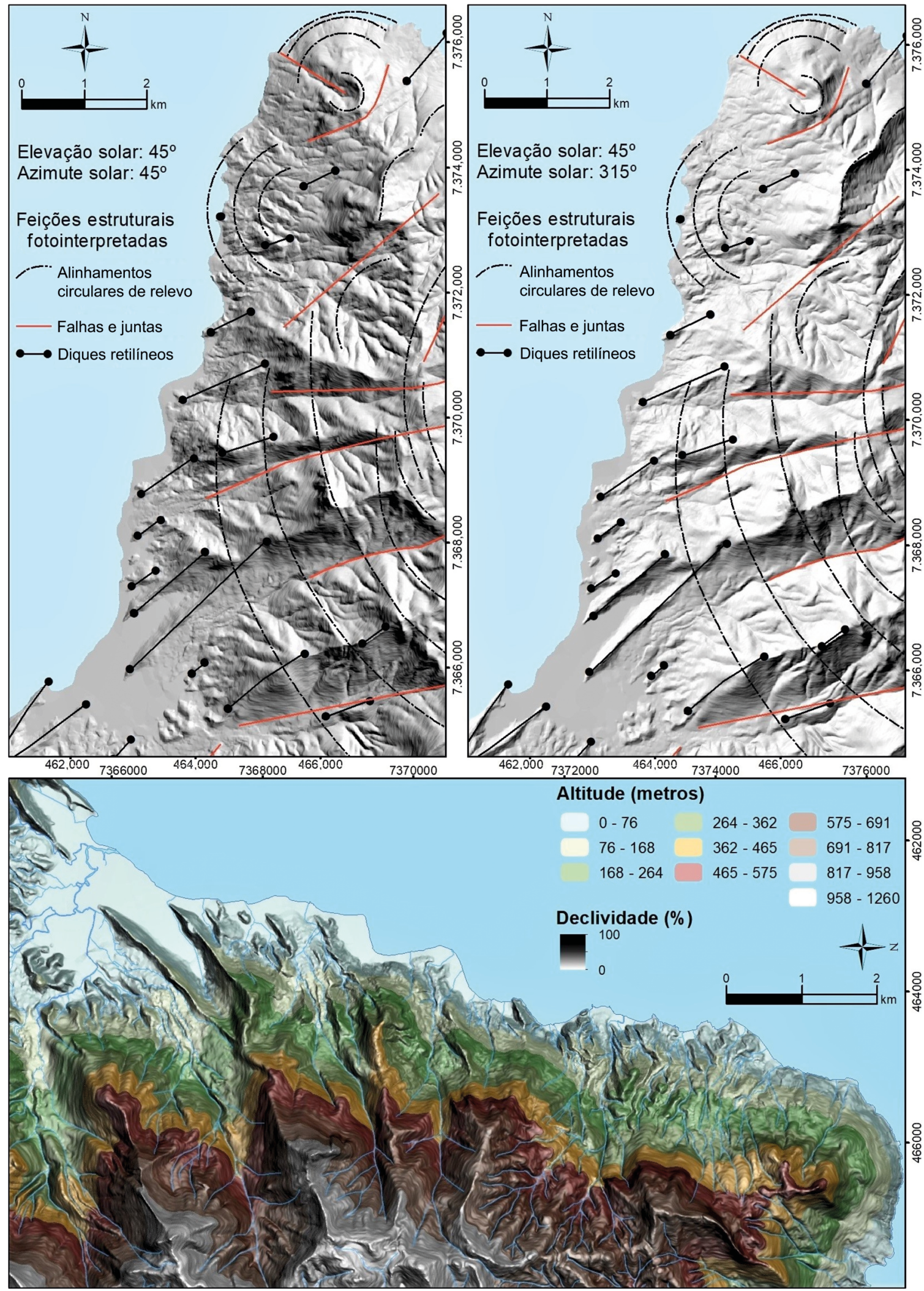

Figura 4. Cartas do relevo sombreado com variações do azimute solar perpendicularmente ao padrão estrutural predominante (NE) e os grandes alinhamentos fotointerpretados (parte superior) e sobreposição da carta hipsométrica com transparência de $60 \%$ à carta de declividade da região nordeste da llha de São Sebastião (parte inferior). 

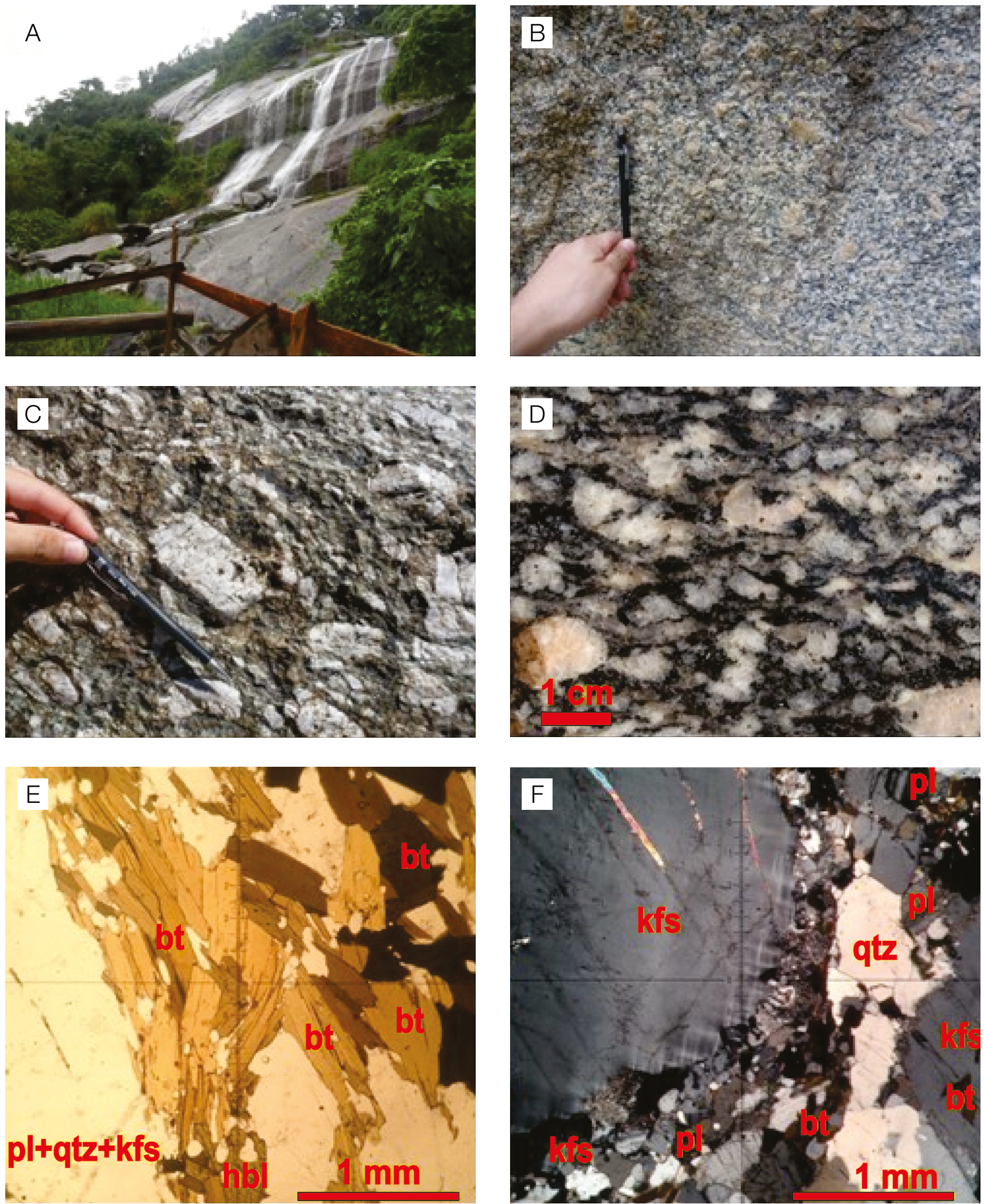

bt: biotita; hbl: hornblenda; kfs: feldspato potássico; pl: plagioclásio; qtz: quartzo.

Figura 5. Gnaisse granítico oftálmico da llha de São Sebastião. (A) Rocha aflorante na forma de lajedo junto à cachoeira, ponto 5. (B) Rocha aflorante no ponto 5. (C) Rocha aflorante na Praia da Serraria. (D) Textura da amostra, do ponto 5. (E) Fotomicrografia sob nicóis paralelos, mostrando bandas de minerais máficos (biotita e hornblenda) entre minerais félsicos (plagioclásio, quartzo e feldspato potássico). (F) Fotomicrografia sob nicóis cruzados, mostrando fenocristal de feldspato potássico de bordas com geminação Tartan, além dos outros minerais constituintes da rocha. 
A foliação nas rochas gnáissicas tem direção predominante nordeste e mergulhos de alto ângulo, acima de $60^{\circ}$, principalmente para noroeste e mais restritamente para sudeste. As principais famílias de fraturas (Figura 8) que ocorrem nas rochas do embasamento apresentam: direção NE com alto ângulo de mergulho para SE, direção EW com alto ângulo de mergulho para $\mathrm{S}$ e direção NW com mergulho variando de alto a médio para NE.

Destaca-se que a família de fraturas de direção NE é subparalela à foliação da rocha. Ambas as estruturas controlam a intrusão do magma e a formação dos diques de ambos os tipos, dado que eles se apresentam subparalelos à foliação (Figura 9), assim como as demais intrusões mesozoicas conforme observadas na Figura 4. Nota-se que o caráter milonítico da foliação é marcante ao longo de toda a área de ocorrência de rochas do embasamento e a ocorrência de diques NE não se condiciona a faixas de maior incidência de feições miloníticas em rochas do embasamento.

\section{Diques associados às feições positivas de relevo}

Diques de andesito porfirítico se associam a grandes cristas retilíneas com vertentes assimétricas, conferindo a esses terrenos maior resistência aos processos intempéricos. Encontram-se intrudidos em rochas granito-gnáissicas, em condições geomorfológicas diversas: morros alongados ao redor da planície do Perequê, espigões junto à linha de costa e escarpas montanhosas adjacentes ao stock da Serraria. Apresentam direção predominante nordeste, subparalela à foliação da rocha encaixante

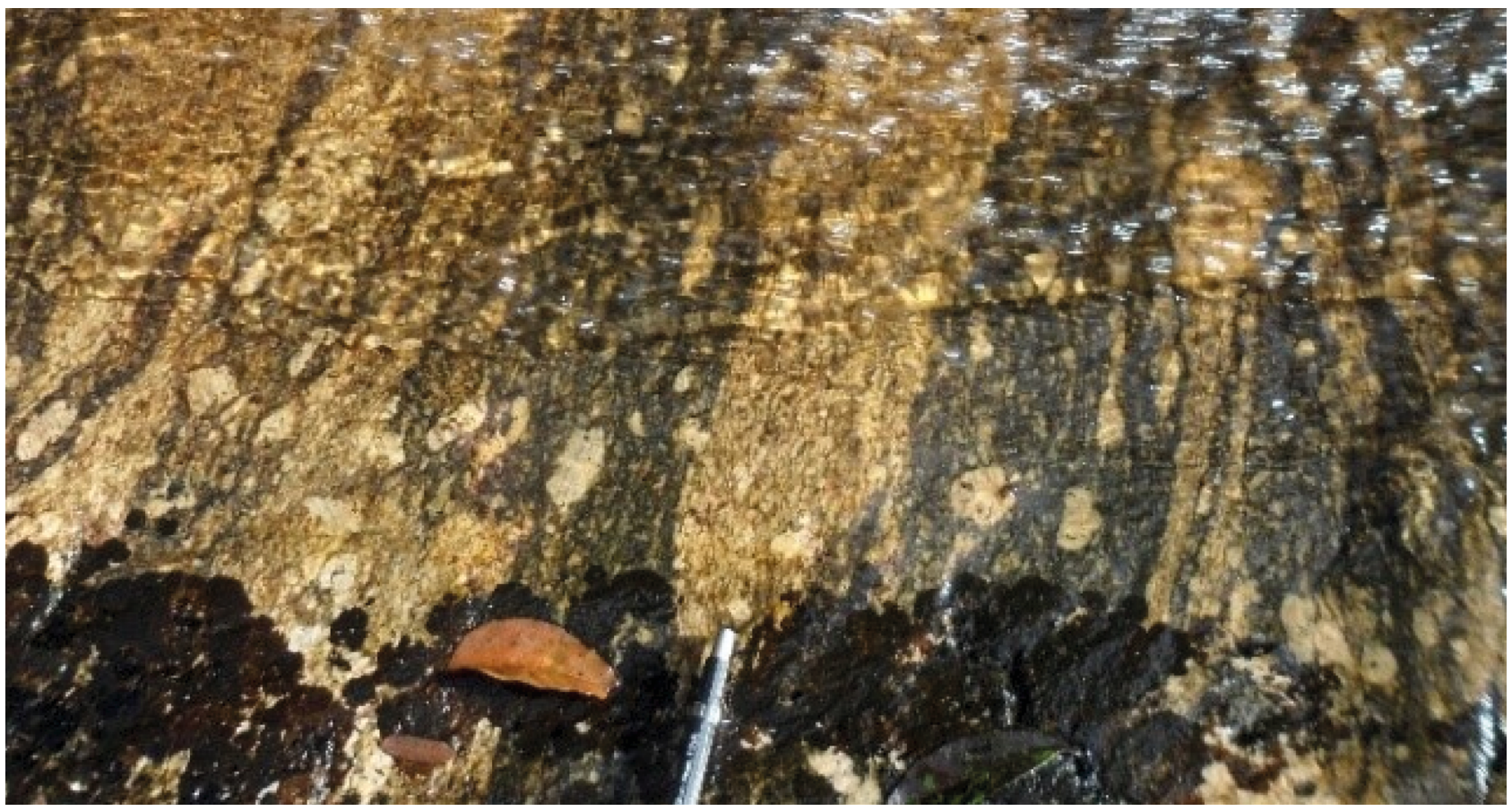

Figura 6. Gnaisse granítico oftálmico com bandamento composicional, ponto 18.
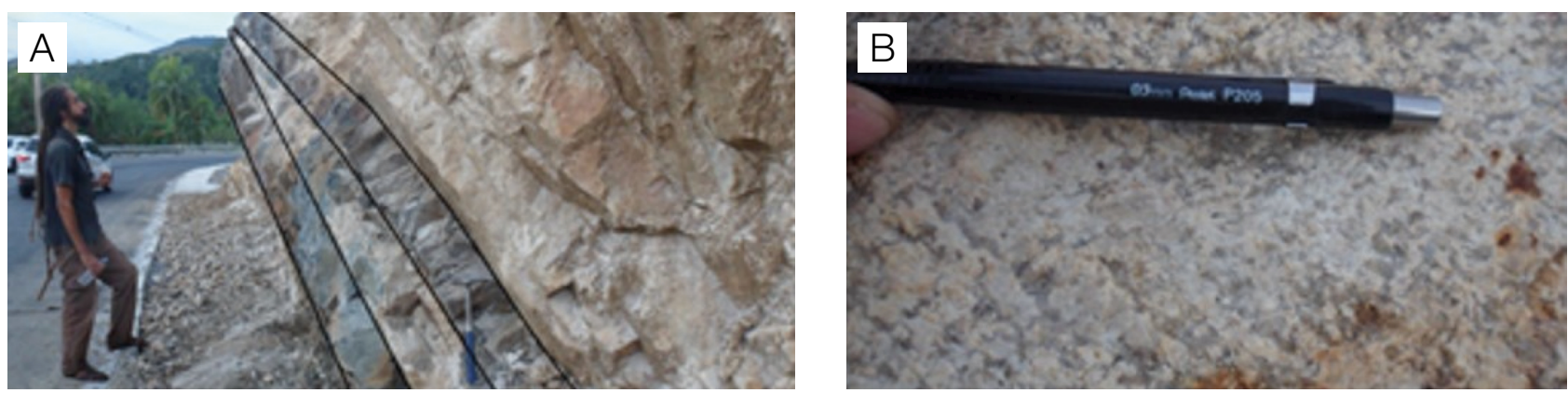

Figura 7. Gnaisse granítico subequigranular, e $(A)$ diques andesíticos de textura afanítica com direção subparalela à foliação (N36E/60SE). (B) Detalhe da textura da rocha do embasamento, pontos 35 e 36. 
e com mergulhos de alto ângulo. Comumente, exibem grandes dimensões, com espessura média de $15 \mathrm{~m} \mathrm{e}$ vários quilômetros de comprimento. Enfatiza-se que tais diques são representados somente por um litotipo, andesito porfirítico.

\section{Caracterização petrográfica}

O andesito porfirítico (Figura 10) apresenta coloração cinza-esverdeada quando fresco e branco-amarelada quando alterado. Mineralogicamente, é composto de plagioclásio (oligoclásio e labradorita), clinopiroxênio (augita), minerais opacos (magnetita/ilmenita) e traços de quartzo e feldspato potássico. Apresenta textura porfirítica, em que fenocristais grossos $(0,4-1 \mathrm{~cm})$ de plagioclásio cinza-esbranquiçado (oligoclásio/labradorita) se encontram inseridos numa matriz fina (menor que $1 \mathrm{~mm}$ ) composta de plagioclásio acinzentado (oligoclásio) e clinopiroxênio preto-esverdeado (augita). Os cristais de augita se mostram intensamente alterados, gerando um produto de alteração esverdeado. Tal alteração pode ser resultado de processos tardi-magmáticos (uralitização) ou de processos intempéricos (formação de argilominerais).

\section{Caracterização do padrão de fraturamento}

A análise completa do padrão de fraturamento de diques exige a descrição das fraturas em mais de uma frente de exposição, uma vez que diques são elementos tridimensionais. A Figura 11 mostra as principais características de cada família identificada. A identificação de fraturas subparalelas a uma face de exposição é problemática caso somente essa face seja analisada. No caso dos diques de composição andesítica, só foi possível a identificação e descrição de fraturas em seções subparalelas à direção nordeste (Figura 12A). Ao longo dessas seções foram descritas quatro principais famílias de fraturas. A Figura 12 ilustra também o bloco-diagrama simplificado com posicionamento tridimensional das respectivas famílias de fraturas.
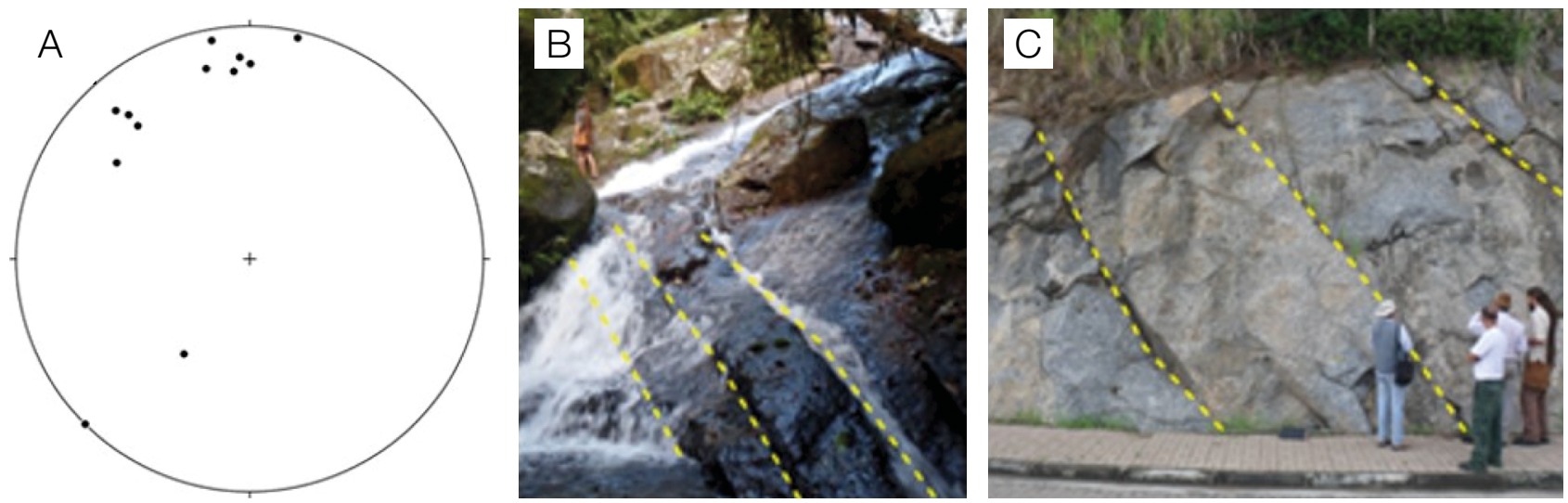

Figura 8. (A) Estereograma apresentando atitudes representativas das três famílias de fraturas nas rochas do embasamento (NE com alto ângulo de mergulho para SE, EW com alto ângulo de mergulho para S e NW com mergulho variando de alto à médio para NE). (B) Família de fraturas subparalelas à foliação de atitude N50E/70SE, em gnaisse granítico oftálmico, ponto 20. (C) Família de fraturas com atitude N84E/75SE, em gnaisse granítico oftálmico, ponto 33.
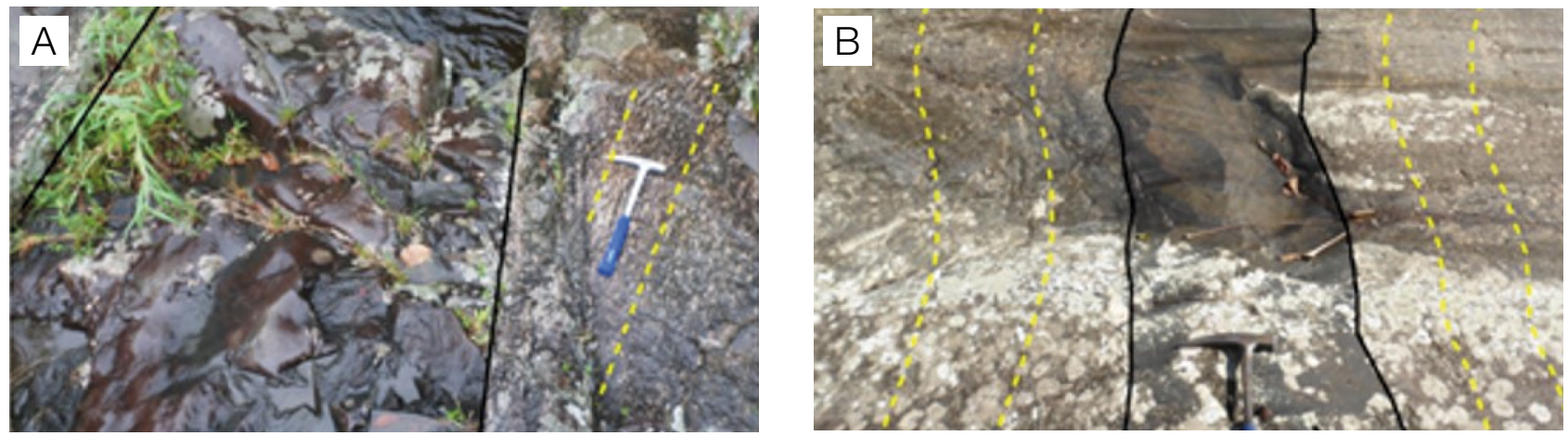

Figura 9. Diques básicos (preto) encaixados em fraturas subparalelas à foliação (amarelo) do gnaisse. Diques de atitudes N50E/65NW, ponto 7 (A) e N27E/65NW, ponto 18 (B). 

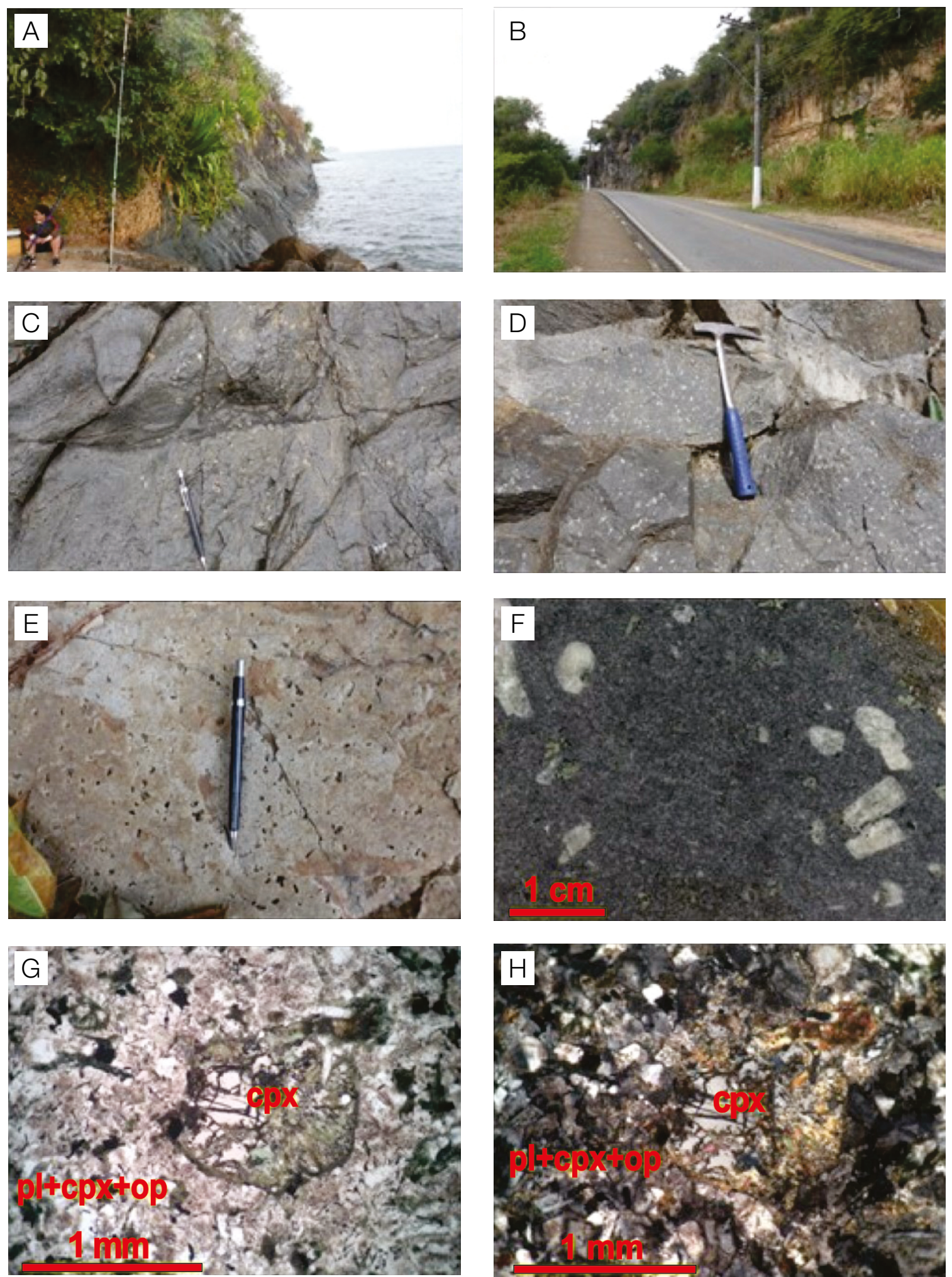

Figura 10. Andesito porfirítico da llha de São Sebastião. (A) Afloramento de grande extensão em costão rochoso retíneo sub-vertical, ponto 11. (B) Rocha aflorante em talude rodoviário, SP-131, ponto 9. (C, D) Detalhe da rocha aflorante nos ponto 11 e 9. (E) Andesito alterado no ponto 11; notar vazios deixados pela alteração dos fenocristais de plagioclásio. (F) Textura da amostra coletada no ponto 13; notar microfenocristais esverdeados produtos de alteração do piroxênio. (G) Fotomicrografia da amostra do ponto 13, sob nicóis paralelos, mostrando microfenocristal alterado de clinopiroxênio (augita) em meio a matriz composta de plagioclásio, clinopiroxênio e opacos, e $(H)$ sob nicóis cruzados. 


\section{Diques associados às feições negativas de relevo}

Esses diques, representados por rochas de composição básica, definem, por vezes, o curso de drenagens, apresentando, portanto, menor resistência ao intemperismo quando comparados à sua rocha encaixante (embasamento granito-gnáissico). É importante notar que outras estruturas, tais como fraturas, também definem a rede de drenagens na área de estudo (Figura 13). Os diques associados a feições negativas são aflorantes ao longo de diversas porções do embasamento e ocorrem com maior frequência do que os diques andesíticos. Tal como os últimos, apresentam direção predominante nordeste, subparalela à foliação da rocha encaixante, com mergulhos de alto ângulo. Exibem dimensões comparativamente menores, com espessura média de $80 \mathrm{~cm}$, podendo chegar até $1,5 \mathrm{~m}$. Os litotipos associados aos diques em questão têm composição básica, sendo representados por diabásios de textura variada.

\section{Caracterização petrográfica}

Duas são as rochas representativas dos diques associados às feições negativas de relevo: diabásio intergranular (Figura 14) e diabásio porfirítico (Figuras 15 e 16). O diabásio intergranular apresenta coloração cinza-escura quando fresco

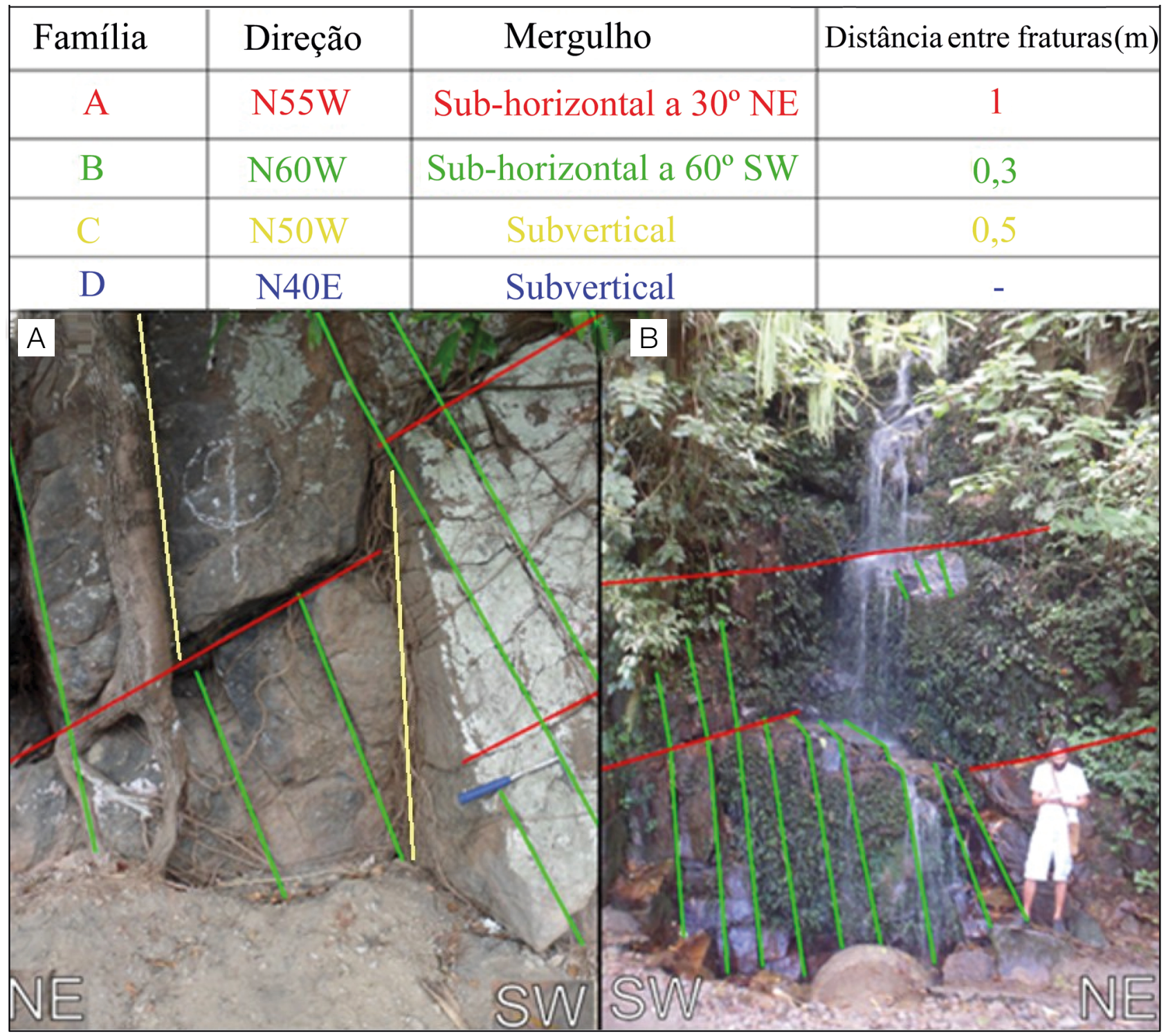

Família A: vermelho; Família B: verde; Família C: amarelo.

Figura 11. Famílias de fraturas nos diques andesíticos no ponto 11 (A) e ponto 1 (B). Não foi possível determinar a distância entre as fraturas da família $\mathrm{C}$, uma vez que as mesmas são subparalelas à seção descrita. 
e tons mais esverdeados quando alterado. A granulação é muito fina, não sendo possível distinguir minerais a olho nu. É composta de plagioclásio (labradorita), clinopiroxênio alterado (augita) e minerais opacos (magnetita/ilmenita).

A textura observada é a intergranular, na qual cristais de labradorita se posicionam entre os cristais de augita. O diabásio porfirítico, por sua vez, também apresenta coloração cinza-escura quando fresco e tende a mostrar tons mais esverdeados quando alterado. É composto de plagioclásio (labradorita), pseudomorfos de minerais ferro-magnesianos (piroxênio e olivina provavelmente), clinopiroxênio (augita) e minerais opacos (magnetita/ilmenita). A identificação dos minerais ferro-magnesianos na forma de fenocristais é dificultada pelo fato de eles se apresentarem intensamente alterados, mostrando substituições pseudomórficas de minerais de alteração (clorita, serpentina, carbonato, idingsita, opacos e argilominerais). A rocha apresenta textura porfirítica, em que fenocristais médios (de até $1 \mathrm{~cm}$ ) de plagioclásio branco acinzentado e de pseudomorfos esverdeados de piroxênio e/ ou olivina se encontram inseridos em matriz fina cinza-escura esverdeada de plagioclásio, clinopiroxênio e minerais opacos. Inseridos nessa matriz fina estão microfenocristais de clinopiroxênio e plagioclásio.

\section{Caracterização do padrão de faturamento}

Foram identificadas três principais famílias de fraturas associadas a esses diques (Figura 17). Cabe ressaltar, no entanto, que, semelhantemente aos diques andesíticos, só foi possível analisar as faces dos diques de diabásio expostas na superfície do terreno, em que as rochas apresentam superfície lisa e uniforme. Consequentemente, foi necessário estimar os ângulos de mergulho referentes às fraturas.

Tanto o padrão de fraturamento dos diques de diabásio quanto dos diques andesíticos apresentam fraturas de direção perpendicular às suas margens (famílias B e B') e fraturas subparalelas à direção do dique (famílias $\mathrm{C}$ e $\mathrm{C}^{\prime}$ ). No entanto, as fraturas nos diques de diabásio exibem um espaçamento menor, ou seja, a densidade de fraturas é maior. Também no caso desses diques não foi possível identificar uma provável família de atitude subparalela à superfície de exposição (Família A), uma vez que não foram encontrados pontos onde os diques aflorassem em seção.

A Família D, como exposto na Figura 17, apresenta direção variável, sempre diagonal em relação às margens dos diques. Constatou-se que a direção de tais fraturas varia de acordo com a direção e a espessura dos diques; quanto maior a espessura, menor o ângulo agudo (a) entre a direção da fratura e a direção do dique (Figura 18).

\section{DISCUSSÃO}

Os diques de diabásio, associados às feições negativas de relevo, apresentam maior proporção de minerais máficos,
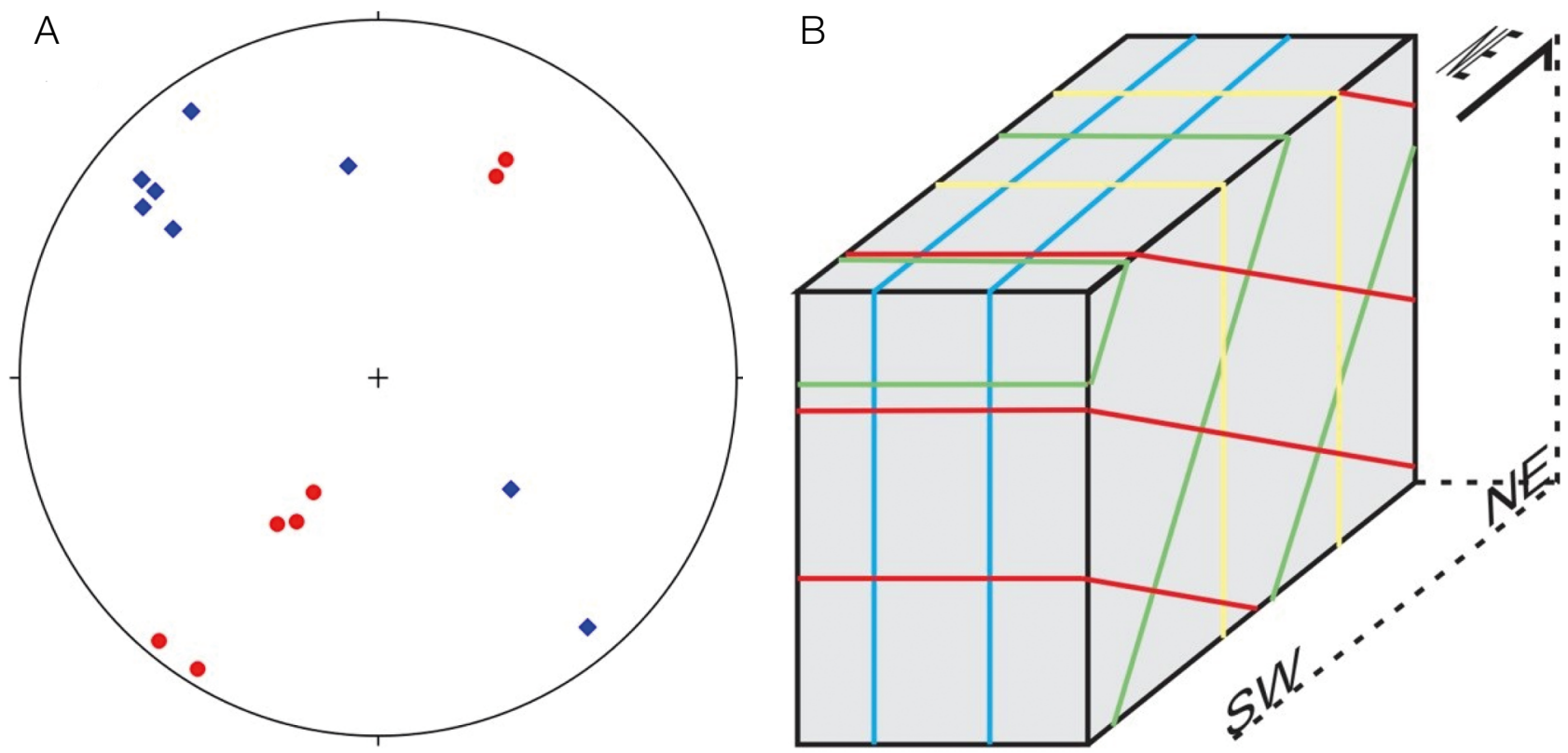

Família A: vermelho; Família B: verde; Família C: amarelo; Família D: azul.

Figura 12. (A) Estereograma: atitudes representativas dos diques andesíticos (direção preferencial NE, diamantes azuis) e famílias de fraturas nos mesmos (direção preferencial NW com mergulhos altos a subvertical e mergulhos máximos para NE e SW, pontos vermelhos). (B) Bloco diagrama: posicionamento das famílias de fraturas nos diques andesíticos. 
tais como piroxênios e possivelmente olivina e, portanto, é esperado que sejam decompostos mais rapidamente que a rocha encaixante (gnaisses graníticos). Além disso, o plagioclásio presente nesses diques é mais rico em cálcio (labradorita), sendo, por isso, mais suscetível ao intemperismo. Por outro lado, os diques andesíticos, associados às feições positivas de relevo, apresentam menor proporção de minerais máficos, sendo que minerais félsicos, como plagioclásio, mostram-se mais abundantes. Essas rochas apresentam uma proporção maior de plagioclásio rico em sódio (oligoclásio), este sendo mais resistente ao intemperismo quando comparado ao
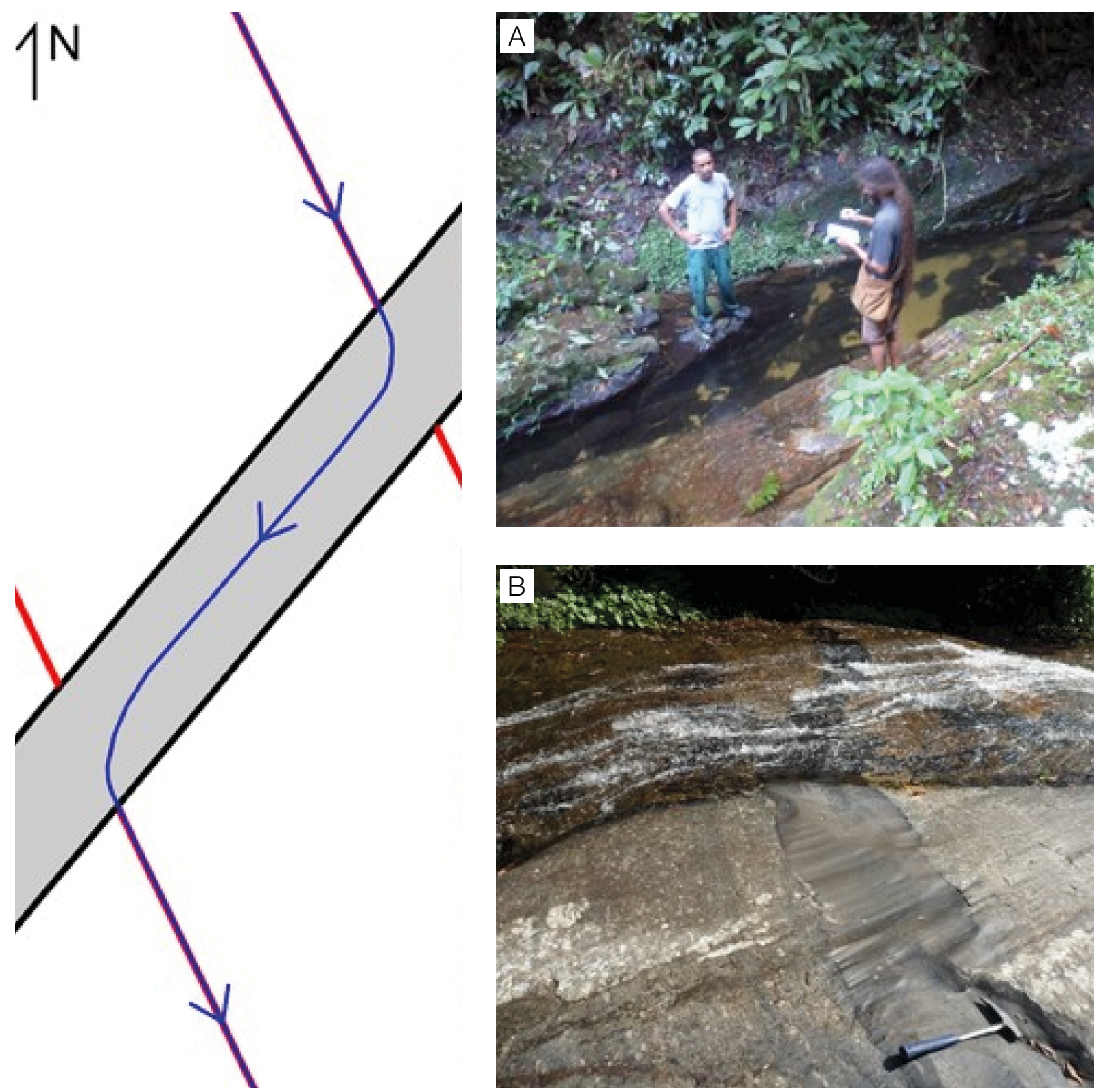

Dique: cinza; Fraturas: vermelho; Curso d'água: azul.

Figura 13. Além dos diques, outras estruturas também podem definir o curso de drenagens. (A) Dique definindo o curso d'água, ponto 19. (B) Curso d'água de direção perpendicular à direção do dique; provavelmente outra estrutura define a direção desse trecho da drenagem, ponto 18. 
plagioclásio nas rochas básicas. No entanto, se a composição mineralógica fosse decisiva na suscetibilidade das rochas ao intemperismo, seria difícil explicar por que os diques andesíticos se apresentam na forma de cristas destacadas em meio aos gnaisses graníticos, haja vista que estes apresentam maior proporção dos minerais mais resistentes. As estruturas presentes nas rochas, tais como foliações e fraturas, também influenciam a sua suscetibilidade ao intemperismo à medida que permitem a entrada de água nos corpos rochosos, fazendo com que sejam intemperizados mais rapidamente.

Os gnaisses graníticos se apresentam foliados e fraturados, enquanto os diques andesíticos têm menor densidade de estruturas, somente fraturas. Além da estruturação dos litotipos, suas idades também são fatores determinantes nas formas de relevo associadas. Por ser mais antigo, o embasamento granito-gnáissico, pré-cambriano, foi submetido a diferentes condições endógenas (campos de tensão) e exógenas (aspectos ambientais) que provavelmente afetaram sua estabilidade, tornando-o mais suscetível ao intemperismo quando comparado ao andesito porfirítico, formado no Cretáceo Inferior.

Ao se comparar os diques andesíticos e de diabásio, constatou-se que ambos têm direções de fraturamento similares, porém o fraturamento dos diques de diabásio apresenta menor espaçamento. Tal comportamento pode ser diretamente correlacionado à espessura dos corpos rochosos, ou seja, quanto menor a espessura da camada, menor tende a ser o espaçamento entre as fraturas (Ladeira e Price, 1981; Ji e Saruwatari, 1998).
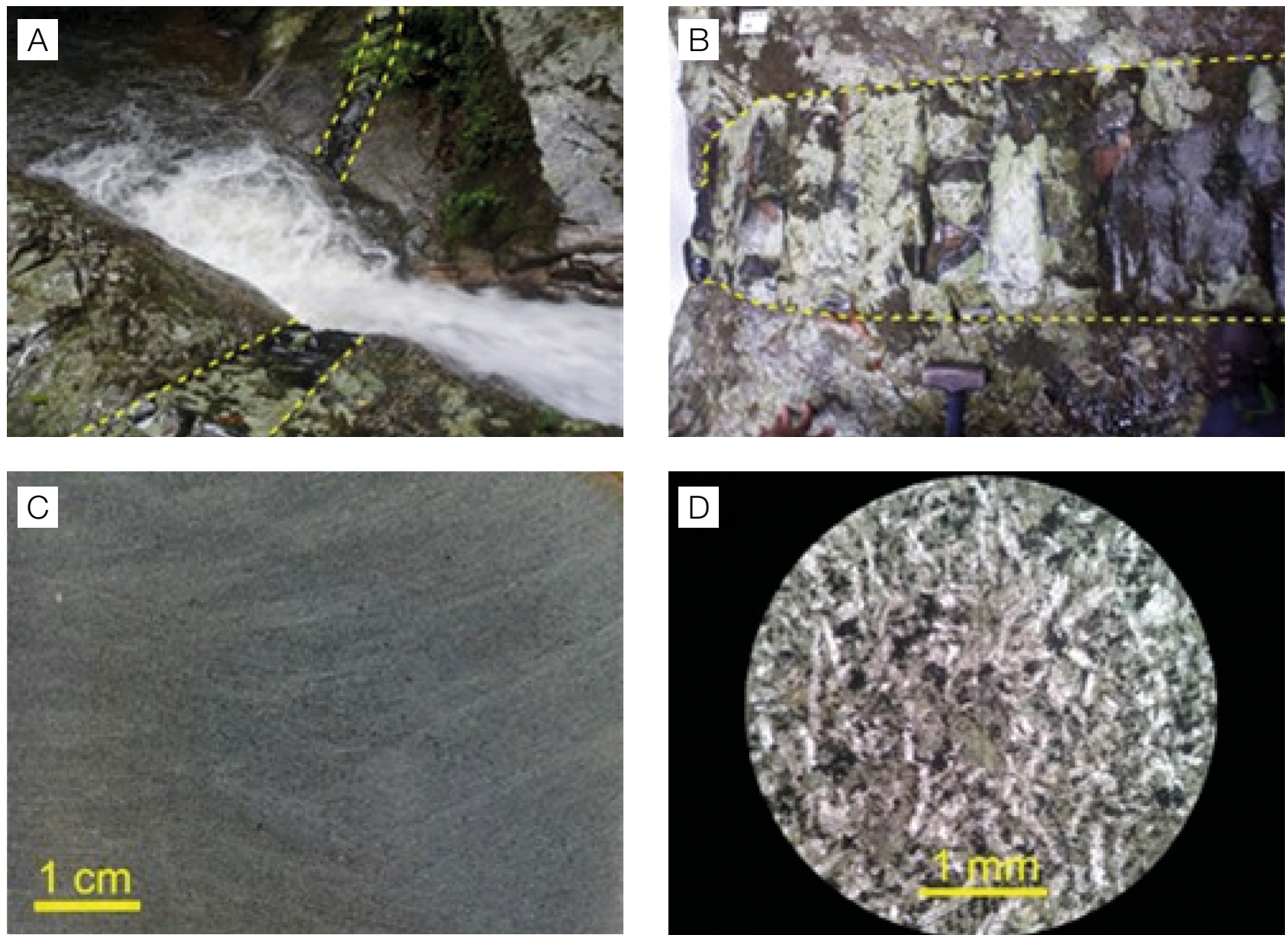

Figura 14. Dique de diabásio intergranular (Direção NE), ponto 4 (A) interceptado por falha (Direção NW) na qual a drenagem corre encaixada. (B) Detalhe do ponto amostrado. (C) Textura da rocha. (D) Fotomicrografia sob nicóis paralelos: textura intergranular, cristais ripiformes de plagioclásio branco ocorrem entre cristais prismáticos de piroxênio alterado esverdeado. 
Logo, os diques de diabásio, com espessuras substancialmente menores $(\sim 80 \mathrm{~cm})$ que diques andesíticos $(\sim 15 \mathrm{~m})$, são mais suscetíveis ao intemperismo, devido à maior densidade de fraturas aliada a uma composição mineralógica menos resistente.

Menor espessura dos diques também implica em menor volume de rocha a ser alterado, o que contribui para uma dissecação mais rápida do relevo associado aos diques de diabásio. Contudo, é importante destacar que as feições positivas de relevo se associam somente às porções mais espessas dos diques andesíticos e que, portanto, essas rochas podem definir formas mais dissecadas de relevo ou até cursos d'água, caso sua espessura seja significativamente menor.

É oportuno destacar o Stock da Serraria, onde os picos montanhosos sustentados por diferentes litotipos alcalinos ultrapassam 1.000 metros de altitude, sendo o relevo com a maior amplitude altimétrica da área estudada. Sua resistência ao intemperismo se deve a:

- idades mais novas, em torno de $80 \mathrm{Ma}$ (Sato, 2006), quando comparadas com o embasamento pré-cambriano;

- dimensões na ordem de dezenas de quilômetros;
- composição maciça e quimicamente mais resistentes ao intemperismo que os demais litotipos mesozoicos.

Quando comparadas com os gnaisses, as rochas alcalinas são menos resistentes ao intemperismo químico, entretanto, a alteração dos minerais primários (nefelina e feldspato) libera sílica utilizada na coesão dos minerais secundários. Esse processo consiste no endurecimento e na impermeabilização causados pela cimentação por hidróxidos dissolvidos na água superficial percolante, reduzindo a susceptibilidade ao intemperismo físico, bem como a percolação da água no interior do corpo rochoso (Dorn, 2004). As rochas alcalinas caracterizam-se ainda pela ausência de foliação e por menor densidade de fraturamento que as rochas gnáissicas, nas quais a foliação contribui para maior percolação da água (Motoki et al., 2007; Motoki et al., 2008).

\section{CONCLUSÃO}

As investigações de campo e a caracterização petrográfica de detalhe, em conjunto com análise geomorfológica, mostraram-se potencial recurso na definição dos principais
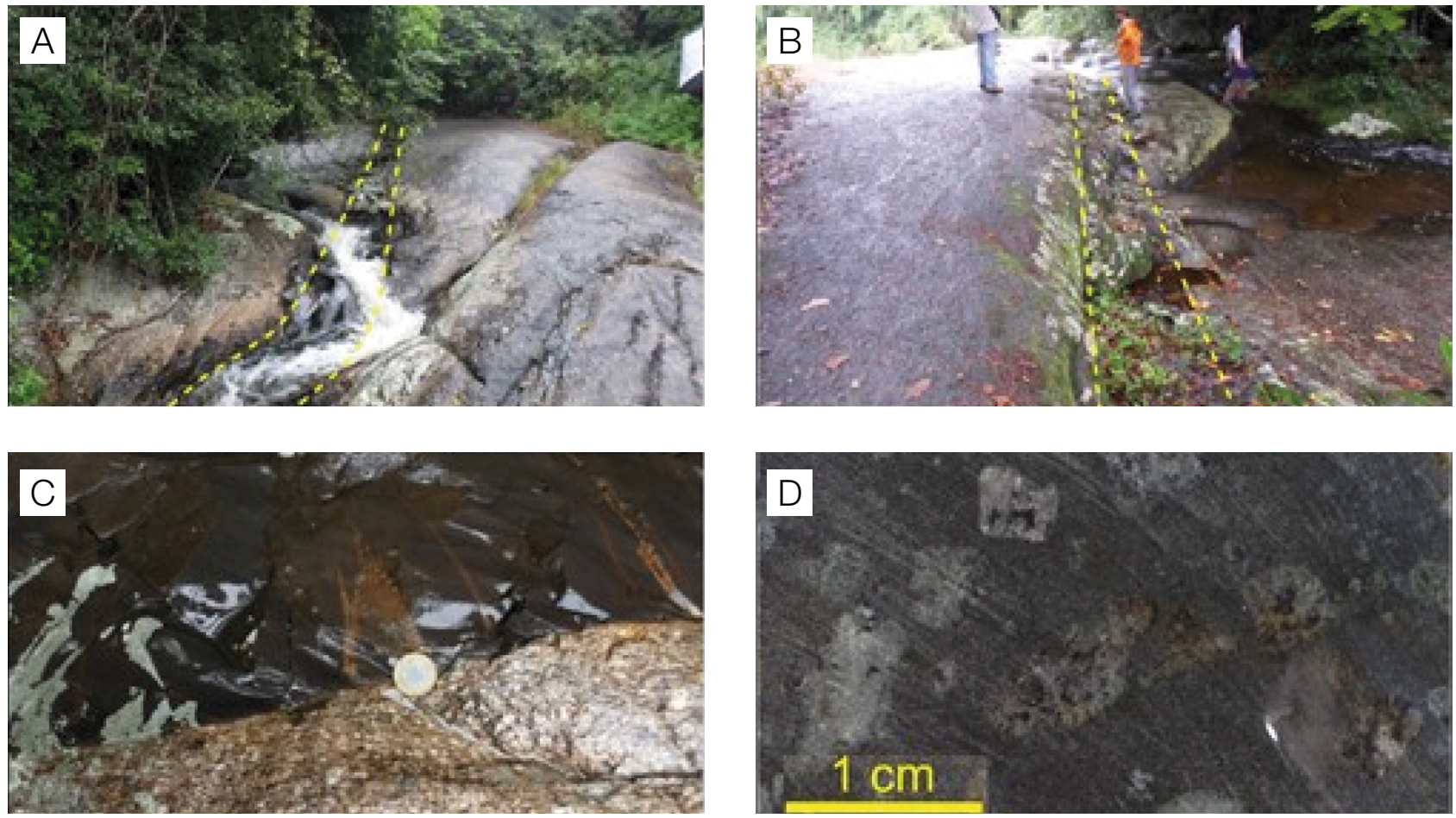

Figura 15. (A) Dique de diabásio porfirítico condicionando drenagem no ponto 7. (B) Drenagem subparalela ao dique, a montante da Figura A. (C) Contato entre o embasamento granito-gnáissico e o dique de diabásio. (D) Fenocristais esbranquiçados de plagioclásio e cristais esverdeados de minerais máficos alterados (piroxênios e possivelmente olivina). 

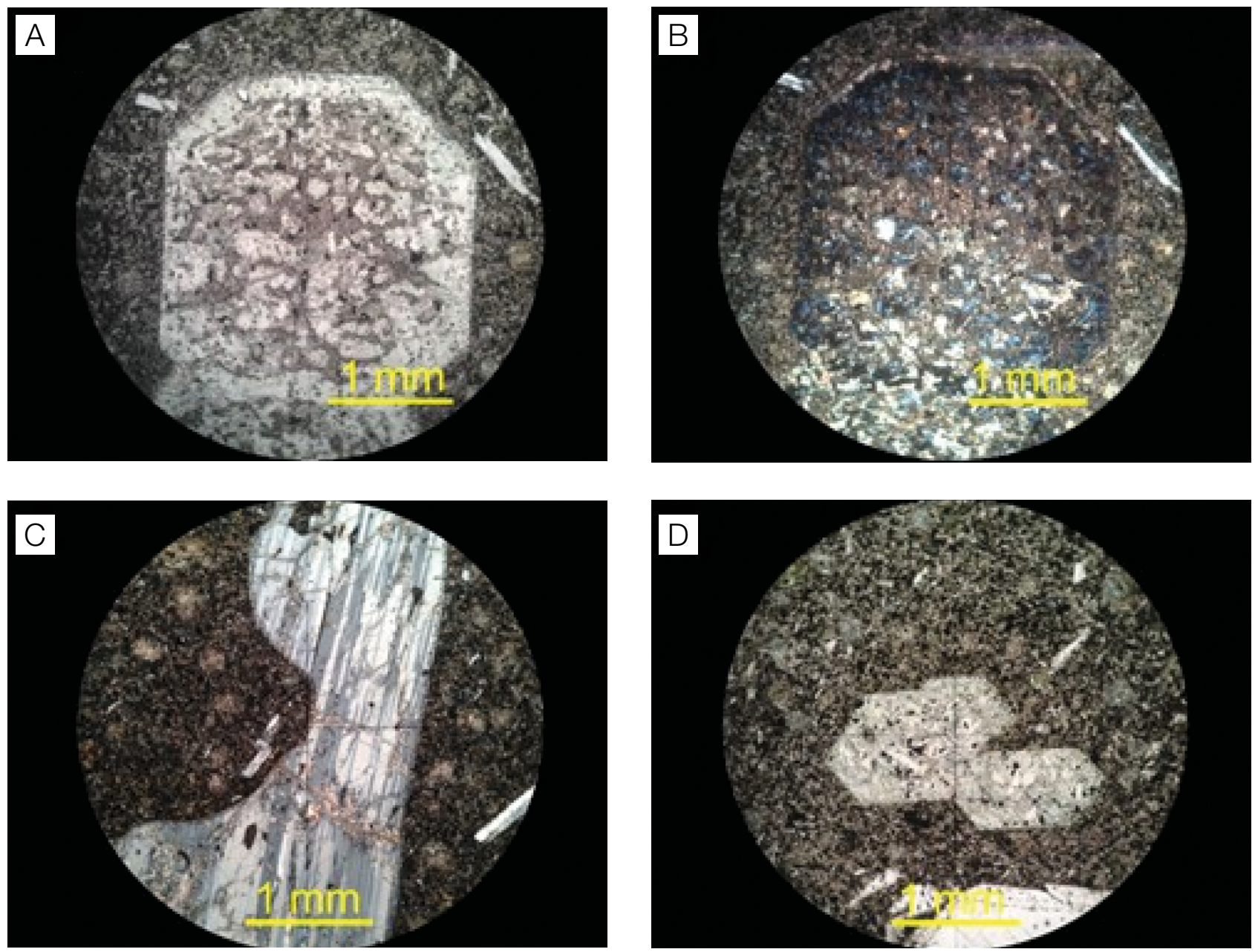

Figura 16. Fotomicrografias do dique de diabásio porfiríticono do ponto 7. (A) Sob polarizadores paralelos mostrando fenocristal euédrico de piroxênio alterado. (B) Sob polarizadores cruzados de fenocristal de piroxênio que mostra clorita de cor anômala como produto de alteração. (C) Sob polarizadores cruzados mostrando fenocristal de plagioclásio corroído em meio a matriz composta de microfenocristais de clinopiroxênio, e cristais de plagioclásio, clinopiroxênio e opacos. (D) Possíveis microfenocristais euédricos de olivina alterada.

parâmetros responsáveis pala geração das diferentes formas de relevo da área estudada. O Tabela 2 apresenta a compilação dos resultados obtidos, permitindo comparar os fatores que condicionam a suscetibilidade ao intemperismo das unidades geológicas caracterizadas.

Uma vez que as rochas alcalinas do Stock da Serraria são as mais resistentes na área estudada, conforme exposto, os diques andesíticos são classificados como a segunda unidade mais resistente aos processos superficiais, devido, principalmente, à composição mineralógica, à estruturação e à espessura dos corpos rochosos e idade.

O embasamento granito-gnáissico é a terceira unidade mais resistente ao intemperismo e à erosão. Tal comportamento está associado principalmente à alta densidade de descontinuidades estruturais (foliação, fraturas, dobras, entre outras) e sua idade mais antiga e consequente exposição aos processos endógenos e exógenos. É de se notar, no entanto, a diversidade geomorfológica associada ao embasamento granito-gnáissico, em decorrência das variações dos litotipos que o compõem, bem como a influência de outras unidades que ocorrem intrudidas nele.

Os diques de diabásio são classificados como a unidade mais susceptível ao intemperismo e, consequentemente, à erosão. A maior porcentagem de minerais máficos, aliada à maior densidade de faturamento, explica tal comportamento.

Conclui-se que, embora restrita à região noroeste da Ilha de São Sebastião, a avaliação de susceptibilidade das unidades geológicas ao intemperismo e erosão pode ser extrapolada ao restante da ilha, à medida que tais condicionantes litoestruturais são observados. Ressalta-se, portanto, a 


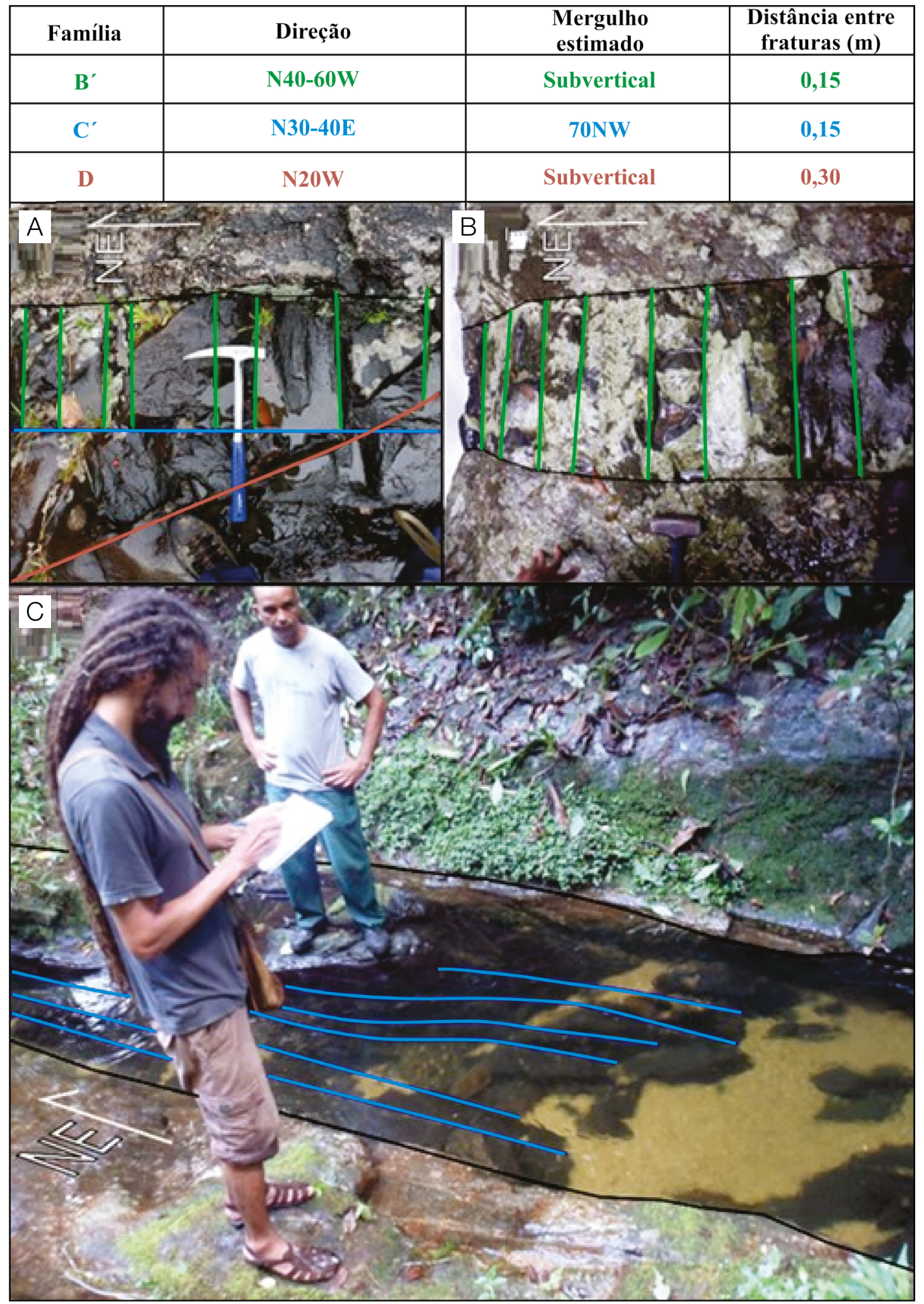

Família B': verde; Família C': azul; Família D: laranja

Figura 17. Características das famílias de fraturas identificadas nos diques de diabásio. (A) Dique de diabásio porfirítico do ponto 7. (B) Dique de diabásio intergranular do ponto 4. (C) Dique de diabásio porfirítico do ponto 19. 
necessidade de estudos envolvendo as demais unidades geológicas existentes no Arquipélago de Ilhabela, reconhecido por sua elevada geodiversidade (Rodrigues, 2018). Nesse sentido, a correlação entre aspectos geológicos e geomorfológicos é indispensável para a compreensão do comportamento do meio físico, cujas implicações são fundamentais para a gestão territorial, especialmente quando consideramos as modificações feitas pelo ser humano.

\section{AGRADECIMENTOS}

Ao Conselho Nacional de Desenvolvimento Científico e Tecnológico (CNPq), à Coordenação de Aperfeiçoamento de Pessoal de Nível Superior (CAPES) e ao Laboratório de Geologia de Engenharia e Meio Ambiente (GEMA/IGCE/ Unesp). Agradecimentos também à Fundação e ao Instituto Florestal do Estado de São Paulo e à Empresa Paulista de Planejamento Metropolitano S.A (EMPLASA).
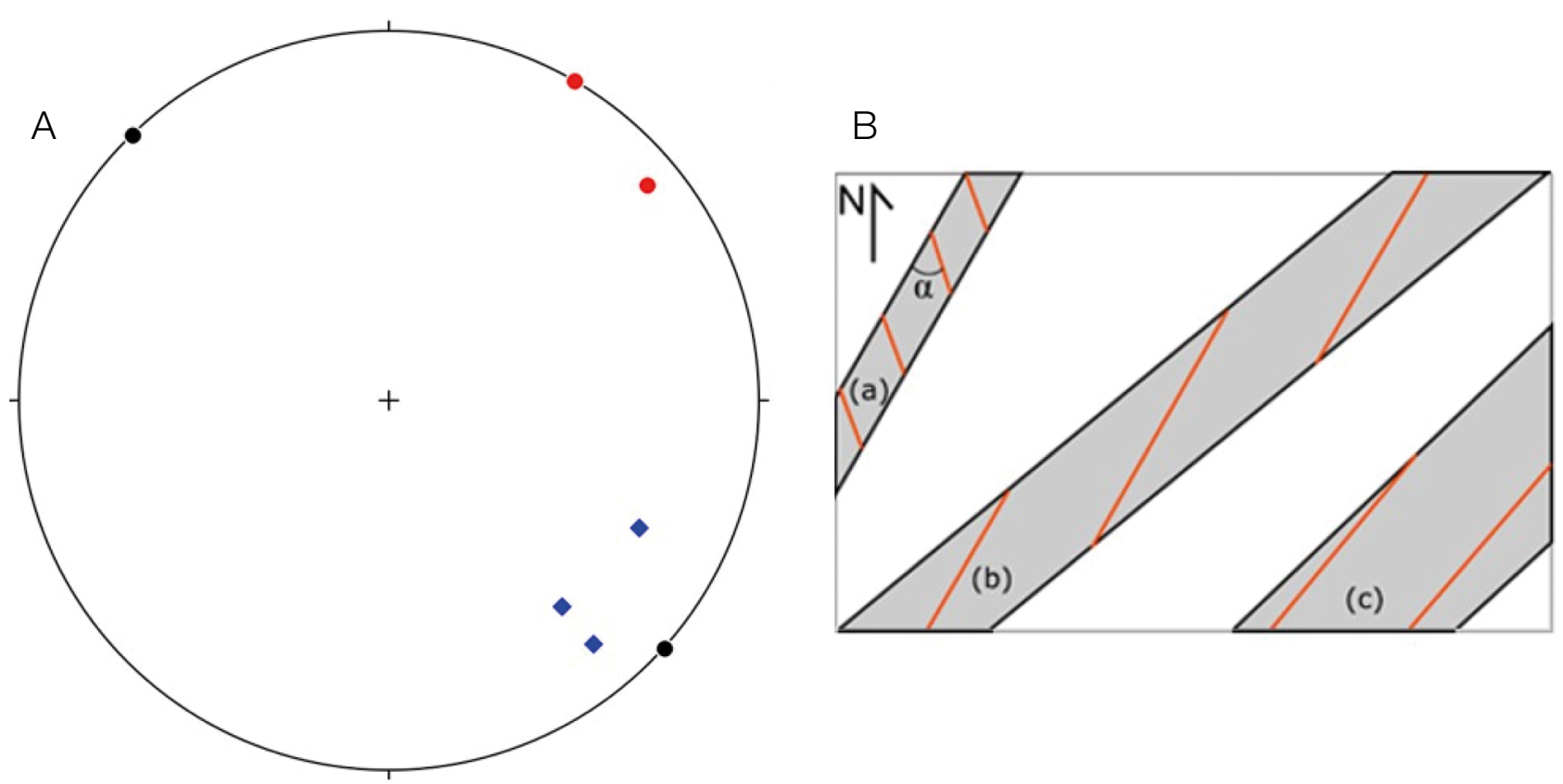

Diques: cinza; Fraturas: laranja; a: ângulo agudo entre a direção da fratura e a direção do dique.

Figura 18. Relação entre a direção das fraturas pertencentes às famílias $\mathrm{B}$ e $\mathrm{C}$ (NW e NE) e as espessuras dos diques de diabásio. (A) Estereograma apresentando direções representativas das famílias B (NW, pontos vermelhos) e C (NE, pontos pretos) e a direção preferencial dos diques (NE, diamantes azuis). (B) Dique descrito no ponto 18, com espessura de 0,4 m, fraturas NW (a). Dique descrito no ponto 7, com espessura de 0,8 $\mathrm{m}$ (b). Dique descrito no ponto 19, com espessura de 1,5 m, fraturas NE (c).

Tabela 2. Condicionantes litoestruturais das formas de relevo da llha de São Sebastião.

\begin{tabular}{|c|c|c|c|}
\hline Fatores & Gnaisses graníticos & Andesito porfirítico & $\begin{array}{c}\text { Diabásios porfiríticos e } \\
\text { intergranulares }\end{array}$ \\
\hline Mineralogia & - & $\begin{array}{l}\text { Maior proporção de plagioclásio } \\
\text { (oligoclásio, labradorita) }\end{array}$ & $\begin{array}{l}\text { Maior proporção de minerais } \\
\text { máficos (clinopiroxênio/augita e } \\
\text { possível olivina) }\end{array}$ \\
\hline Espessura & - & $15 \mathrm{~m}$ & $0,8 \mathrm{~m}$ \\
\hline Estruturas & $\begin{array}{c}\text { Foliação e famílias de fraturas } \\
\text { subparalelas, e de atitude } \\
\text { N84E/75SE }\end{array}$ & $\begin{array}{l}\text { Ausência c } \\
\text { Menor densidade de fraturamento, } \\
\text { com distâncias entre fraturas de } \\
30 \mathrm{~cm} \text { e } 1 \mathrm{~m} \text {. }\end{array}$ & $\begin{array}{l}\text { le foliação } \\
\text { Maior densidade de fraturamento, } \\
\text { com distâncias entre fraturas de } \\
\qquad 15 \text { e } 50 \mathrm{~cm} .\end{array}$ \\
\hline Idade & Pré-Cambriano & Eocretáceo & Eocretáceo \\
\hline $\begin{array}{l}\text { Relevo } \\
\text { associado }\end{array}$ & $\begin{array}{c}\text { Morros, morrotes e encostas } \\
\text { montanhosas }\end{array}$ & $\begin{array}{l}\text { Escarpas e morros com cristas } \\
\text { alongadas e encostas assimétricas }\end{array}$ & Vales assimétricos e encaixados \\
\hline
\end{tabular}




\section{REFERÊNCIAS}

Almeida, F. F., Hasui, Y., Ponçano, W. L., Dantas, A. S. L., Carneiro, C. D. R., Melo, M. D., Bistrichi, C. A. (1981). Mapa geológico do Estado de São Paulo. IPT-Série Monografias-6. São Paulo, Conservação e uso sustentável da biodiversidade florestal na mata atlântica do Vale do Ribeira.

Anjos, C. E., Veneziani, P. (1993). Integração de dados geológicos, geomorfológicos, e de solos obtidos de Imagens TM-Landsat para confecção de carta geológica na região do Vale do Paraíba e Litoral Norte de São Paulo. VII Simpósio Brasileiro de Sensoriamento Remoto, p. 152-158.

Barreto, G. S. (2016). Geologia dos granitos porfiriticos de Ilhabela-Petrogênese e evolução crustal. Dissertação (Mestrado). São Paulo: Instituto de Geociências - USP. https://doi.org/10.11606/D.44.2017.tde-28032017-081002

Diniz, T. D., Zaine, J. E., Rodrigues, F. H. (2016). Compartimentação fisiográfica aplicada ao mapeamento em detalhamento progressivo do núcleo urbano central de Ilhabela-SP. Geologia USP. Série Cientifica, 16(3), 57-70. https://doi.org/10.11606/issn.2316-9095.v16i3p57-70

Dorn, R. I. (2004). Case hardening. In: Goudie, A. S. (Ed). Encyclopedia of geomorphology (1, 118-119). London: Routledge.

Empresa Paulista de Planejamento Metropolitano (EMPLASA). (2011). Projeto de Atualização Cartográfica do Estado de São Paulo - Mapeia São Paulo. Fotografias aéreas (108, dig., col., estereosc., ground sample distance $45 \mathrm{~cm}$ ) e ortofotos (9, dig., col., resolução aproximada $1 \mathrm{~m}$ ) do município de Ilhabela (SP). São Paulo, EMPLASA.

França,A. (1954). A Ilha de São Sebastião. Boletim da Faculdade de Filosofia Letras e Ciências Humanas - USP, 178(10). 108 p.

Freitas, R. O. (1944). Geomorfogênese da Ilha de São Sebastião. Boletim da Associação dos Geógrafos Brasileiros, 4(4), 16-30.

Freitas, R. O. (1947). Geologia e petrologia da Ilha de São Sebastião. Boletim da Faculdade de Filosofia, Ciências e Letras, 85. 244 p.

Fundação Florestal do Estado de São Paulo (FFSP) (2015). Plano de Manejo do Parque Estadual de Ilhabela. São Paulo, FFSP. Disponível em: < http://fflorestal.sp.gov.br/pagina-inicial/ planos-de-manejo/planos-de-manejo-planos-concluidos/planode-manejo-pe-ilhabela/>. Acesso em: 3 dez. 2016.

Garda, G. M. (1995). Os Diques Básicos e Ultrabásicos entre as cidades de São Sebastião e Ubatuba, Estado de São Paulo. Tese (Doutorado). São Paulo: Instituto de Geociências - USP. https://doi.org/10.11606/T.44.1995. tde-20032013-160227

Griffiths, J. S., Stokes, M., Stead, D., Giles, D. (2012). Landscape evolution and engineering geology: results from IAEG Commission 22. Bulletin of Engineering Geology and the Environment, 71(4), 605-636. https://doi.org/10.1007/ s10064-012-0434-7

Hasui, Y. (2012). Sistema Orogênico Mantiqueira. In: Y. Hasui, C. D. R. Carneiro, F. F. M. Almeida, A. Bartorelli (orgs.) Geologia do Brasil (331-372). São Paulo: Bec.

Hasui, Y., Fonseca, M. J. G., Ramalho, R. (1984). A parte central da Região de Dobramentos Sudeste e o Maciço Mediano de Guaxupé. In: C. Schobbenhaus, D. A. Campos, G. R. Derze, H. E. Asmus (Coords.). Geologia do Brasil (307-328). Brasília: DNPM.

Hennies, W. T., Hasui, Y. (1968). Geocronologia das rochas eruptivas da Ilha de São Sebastião, SP. XXII Congresso Brasileiro de Geologia, p. 145-148. Belo Horizonte: SBG.

Hennies, W. T., Hasui, Y. (1977). Contribuição ao reconhecimento da ilha de São Sebastião. I Simpósio Regional de Geologia, 613-654. São Paulo: SBG.

Instituto Brasileiro de Geografia e Estatística (IBGE). (2010). Censo Demográfico 2010. Rio de Janeiro: IBGE. Disponível em: $<$ https://cidades.ibge.gov.br/brasil/sp/ilhabela/panorama $>$. Acesso em: 3 fev. 2017.

Instituto Geográfico e Cartográfico do Estado de São Paulo (IGC) (1978). Mapeamento Topográfico - escala 1:10.000. Cartas topográficas do município de Ilhabela (SP), 32, P\&B, levantamento aereofotogramétrico. São Paulo: Terrafoto S.A.

Ji, S., Saruwatari, K. (1998). A revised model for the relationship between joint spacing and layer thickness. Journal of Structural Geology, 20(11), 1495-1508. https:// doi.org/10.1016/S0191-8141(98)00042-X

Ladeira, F. L., Price, N. J. (1981). Relationship between fracture spacing and bed thickness. Journal of Structural Geology, 3(2), 179-183. https://doi.org/10.1016/0191-8141(81)90013-4

Lima, G. A. (2001). Gabros estratiformes da região norte da Ilha de São Sebastião, SP. Dissertação (Mestrado). São Paulo: Instituto de Geociências - USP. https://doi. org/10.11606/D.44.2001.tde-25092015-160340 
Magalhães, F. S., Cella, P. R. C. (1998). Estruturas do Maciços Rochosos. In: A. M. S. Oliveira, S. N. A. Brito (orgs.). Geologia de Engenharia (38-55). São Paulo: ABGE.

Montes-Lauar, C. R. (1993). Paleomagnetismo de rochas magmáticas mesozóico-cenozóicas da Plataforma Sul-Americans: estudo das formações Anari (RO) e Tapirapuã (MT), da Ilha de São Sebastião (SP), dos complexos alcalinos-carbonatíticos de Tapira (MG) e Salitre (MG) e das ilhas do Arquipélago dos Abrolhos. Tese (Doutorado). São Paulo: Instituto de Astronomia, Geofísica e Ciências Atmosféricas - Universidade de São Paulo.

Motoki, A., Petrakis, G. H., Sichel, S. E., Cardoso, C. E., Soares, R., Motoki, K. F. (2008). Origem dos relevos do Maciço Sienítico do Mendanha, RJ, com base nas análises geomorfológicas e sua relação com a hipótese do Vulcão de Nova Iguaçu. Geociências, 27(1), 97-113.

Motoki, A., Soares, R., Sichel, S. E., Aires, J. R., Lobato, M. (2007). Feições intempéricas em rochas alcalinas félsicas de Nova Iguaçu, RJ. REM-Revista Escola de Minas, 60(3), 451458. http://dx.doi.org/10.1590/S0370-44672007000300003

Pabst, L. (2014). Gabros estratiformes e sienitos supersaturados da Ilha de São Sebastião, SP: Relações geológicas e petrografia na região da Ponta da Sepituba. Monografia (Trabalho de Conclusão de Curso). São Paulo: Instituto de Geociências - USP.

Penck, W. (1953). Morphological analysis of land forms: a contribution to physical geology. Londres: MacMillan.

Ramalho, R. (1982). Geomorfologia. In: D. K. Chiodi, A. M. G. Theodorovicz, A. Theodorovicz, M. Silva, J. P. Algarte, F. Battola Junior, C. Chiodi Filho, R. Ramalho, E. Breitag. Projeto Planejamento Minerário na Ocupação do Solo em Área de Atuação da SUDELPA. São Paulo: SUDELPA / CPRM. v. 2. Anexo 5 - Mapa Geomorfológico.

Riccomini, C., Velásquez, F. V., Gomes, C. B. (2005). Tectonic controls of the Mesozoic and Cenozoic alkaline magmatism in the central-southeastern Brazilian Platform. In: P. Comin-Chiaramonti, C. B. Gomes (orgs.). Mesozoic to Cenozoic Alkaline Magmatism in the Brasilian Platform (31-56). São Paulo: Edusp/Fapesp.

Rodrigues, F. H. (2018). Estudo da geodiversidade da região norte da Ilha de São Sebastião (SP): uma proposta de mapeamento geoambiental aplicado à estratégia de geoconservaçã. Tese (Doutorado). Rio Claro: Instituto de Geociências e Ciências Exatas - UNESP.

Rodrigues, F. H., Zaine, J. E. (2013). Mapeamento geológicogeotécnico da estrada de Castelhanos, Ilhabela (SP). Revista Brasileira de Geologia de Engenharia e Ambiental, 159-172.
Ross, J. L. S. (1992). O registro cartográfico dos fatos geomorfológicos e a questão da taxonomia do relevo. Revista do Departamento de Geografia, 6, 17-29. https:// doi.org/10.7154/RDG.1992.0006.0002

Rossi, M., Menk, J. R. F., Aguiar Mattos, I. F., Catarucci, A. F. (2005). Análise da fragilidade do meio físico para as ilhas de São Sebastião e dos Búzios; estudo de caso. Analysis of the physical environment fragility for São Sebastião and Búzios islands\&58; case study. Revista do Instituto Florestal, 17(2), 161-181.

Santos, A. R. (1994). Fundamentos filosóficos e metodológicos da geologia de engenharia. Comunicação Técnica. São Paulo: Instituto de Pesquisas Tecnológicas do Estado de São Paulo. n. 2088.

Sato, E. N. (2006). Petrografia e geocronologia U/Pb (TIMS) de rochas alcalinas da Ilha de São Sebastião (SP). Monografia (Trabalho de Conclusão de Curso). São Paulo: Instituto de Geociências - USP.

Schobbenhaus, C., Brito Neves, B. B. (2003). A geologia do Brasil no contexto da Plataforma Sul-Americana. Geologia, Tectônica e Recursos Minerais do Brasil. Brasília: CPRM, p. 5-25.

Silva, A. T. S. F., Chiodi Filho, C., Chiodi, D. K., Pinho Filho, W. D. (1977). Projeto Santos-Iguape. Relatório Técnico. Brasil: Ministério de Minas e Energia. Convênio DNPM-CPRM. 3 v.

Soares, P. C., Fiori, A. P. (1976). Lógica e sistemática na análise e interpretação de fotografias aéreas em geologia. Notícia Geomorfológica, 16(32), 71-104.

Timich, M., Azzone, R. G. A., Rojas, G. E. R., Silva Folho, S. V. M. (2016). Relações de contato entre rochas alcalinas máficas e sieníticas na praia do Jabaquara, setor $\mathrm{N}$ da Ilha de São Sebastião, SP. XLVIII Congresso Brasileiro de Geologia. Anais: as geotecnologias e o século XXI. Porto Alegre: SBG. Tinós, T. M., Ferreira, M. V., Zaine, J. E., Riedel, P. S. (2014). Técnicas de Visualização de Modelos Digitais de Elevação para o Reconhecimento de Elementos de Análise do Relevo. Geociências, 33(2), 202-215.

Zaine, J. E. (2011). Método de fotogeologia aplicado a estudos geológico-geotécnicos: ensaio em Poços de Caldas, MG. Tese (Livre-Docência). Rio Claro: Instituto de Geociências e Ciências Exatas - UNESP. 